\title{
Impact of Biomass Burning on Air Quality in Temuco City, Chile
}

Aerosol and Air Quality Research

\section{OPEN ACCESS}

Received: May 14, 2021

Revised: August 31, 2021

Accepted: September 5, 2021

${ }^{*}$ Corresponding Author:

Hilkka.Timonen@fmi.fi

\section{Publisher:}

Taiwan Association for Aerosol Research

ISSN: $1680-8584$ print

ISSN: 2071-1409 online

Copyright: The Author(s). This is an open access article distributed under the terms of the Creative Commons Attribution License (CC BY 4.0), which permits unrestricted use, distribution, and reproduction in any medium, provided the original author and source are cited.

\section{Felipe Reyes ${ }^{1}$, Sofía Ahumada ${ }^{1}$, Francisca Rojas ${ }^{1}$, Pedro Oyola ${ }^{1}$, Yeanice Vásquez ${ }^{1}$, Claudio Aguilera ${ }^{1}$, Andres Henriquez ${ }^{1}$, Ernesto Gramsch ${ }^{2}$, Choong-Min Kang ${ }^{3}$, Sanna Saarikoski ${ }^{4}$, Kimmo Teinilä ${ }^{4}$, Minna Aurela ${ }^{4}$, Hilkka Timonen ${ }^{4,5 *}$}

${ }^{1}$ Centro Mario Molina Chile, Santiago, Chile

${ }^{2}$ Physics Department, Universidad de Santiago de Chile, Santiago, Chile

${ }^{3}$ Department of Environmental Health, Harvard T.H. Chan School of Public Health, Boston, USA

${ }^{4}$ Atmospheric Composition Research, Finnish Meteorological Institute, Helsinki, Finland

${ }^{5}$ Aerosol Physics Laboratory, Physics Unit, Tampere University, Tampere, Finland

\section{ABSTRACT}

Residential wood burning emits a complex mixture of particulate and gaseous compounds. In this article we show an in-depth chemical characterization of particulate matter evidencing the impact of biomass burning on the urban air quality in Greater Temuco, the capital city of the Araucanía Region, Chile. The measurements were carried out at two sites, Las Encinas and Padre Las Casas, in spring and winter. Extremely high fine particulate matter $\left(\mathrm{PM}_{2.5}\right)$ concentrations (up to $700 \mu \mathrm{g} \mathrm{m}^{-3}$ ) were frequently observed at both stations in the wintertime, while in spring, $\mathrm{PM}_{2.5}$ concentrations were significantly lower (campaign-average 6.4 and $8.6 \mu \mathrm{g} \mathrm{m}^{-3}$ in Las Encinas and Padre Las Casas, respectively). Chemical composition of submicron PM was dominated by organics (average $87 \%$ ) followed by inorganic ions (10-30\%) and a minor contribution of black carbon $(<5 \%)$. In the wintertime, atmospheric levels of biomass burning tracers, such as levoglucosan, potassium and chloride, were elevated and their diurnal profiles showed a significant concentration increase in the evening. Diurnal profiles combined with the in-depth chemical analysis clearly indicated that in the wintertime local biomass burning was the main source of air pollutants in the region. Furthermore, in winter, most of the high concentration events correlated with the periods with high surface pressure, low temperature and low wind speed. These events matched with higher temperatures at high altitude than at the surface characterizing the typical profile of a vertical inversion that prevents the dilution of air pollutants.

Keywords: Particulate matter, Residential biomass burning, Chemical composition, Elemental composition

\section{INTRODUCTION}

Air pollutants have serious impact on air quality, human health, and climate (Jorquera et al., 2018). Due to strict emission limits set to vehicles and industry, biomass combustion for domestic heating and cooking is nowadays often the biggest source of particulate emissions in the residential areas (e.g., Chen et al., 2017; Helin et al., 2018). Biomass combustion emits a complex mixture of particulate and gaseous pollutants to the atmosphere that are further oxidated and processed in the atmosphere forming secondary aerosol (Sumlin et al., 2017, Kortelainen et al., 2018, Fang et al., 2021). The magnitude and composition of biomass combustion emissions depends strongly on the type of biomass, burning conditions as well as the burning device (Chen et al., 2017, Kortelainen et al., 2018). Besides residential burning, biomass combustion emissions can also be caused by other sources such as forest fires and prescribed burning. The frequency and severity of forest 
fires have increased in many areas in the last decades with some fires located at the interface of wildland and urban areas directly affecting the inhabitants living in the cities (Burling et al., 2011; Lindenmayer and Taylor, 2020). In some countries, the intentional agricultural burning is also widely carried out (Holder et al., 2017), and the smokes from the fires often drift to the densely populated urban areas causing health and environmental issues (Mehmood et al., 2018, 2020).

Biomass burning causes a serious pollution problem in southern Chile. Around 2 million people, who live in the area, are exposed annually to ambient fine particulate matter $\left(\mathrm{PM}_{2.5}\right)$ concentrations greater than $30 \mu \mathrm{g} \mathrm{m}^{-3}$ that significantly exceeds Chile's primary annual $\mathrm{PM}_{2.5}$ standard limit of $20 \mathrm{~g} \mathrm{~m} \mathrm{~m}^{-3}$ (Jorquera et al., 2018). In the last decade, the ambient PM concentrations have been increasing, and the studies based on the PM chemical analyses have shown that the combustion of wood in household stoves is the main source of ambient air pollution in southern Chile (Cereceda-Balic et al., 2012; Díaz-Robles et al., 2014; Jorquera et al., 2018). As the adverse health effects of PM have been well documented (e.g., Lelieveld et al., 2015), the PM exposure is recognized as a major contributor to health impairment in the southern region of Chile (Díaz-Robles et al., 2015, 2014; Sanhueza et al., 2009; Schueftan and González, 2015).

The aim of this article is to show a detailed analysis of the chemical composition of PM in an urban area where residential wood combustion is widely used. By carrying out two sampling campaigns in winter and springtime, we show that in wintertime wood combustion is the main contributor to PM in the area and a major source of air pollution. State-of-the art instrumentation, in-depth real time PM characterization and meteorological endpoints were used to characterize the main chemical fractions, including organic matter, inorganic ions as well as elements, in PM2.5.

\section{EXPERIMENTAL}

\subsection{Sampling Site and Measurement Campaign}

The measurement campaigns were conducted at two sites, Las Encinas (LE; 38 $44^{\prime} 55.38^{\prime \prime S}$, 72 ${ }^{\circ} 37^{\prime} 14.54^{\prime \prime} \mathrm{W}$ ) and Padre Las Casas (PLC; 38 ${ }^{\circ} 45^{\prime} 53.03^{\prime \prime S}, 72^{\circ} 35^{\prime} 55.65^{\prime \prime} \mathrm{W}$ ), that were both located in Greater Temuco, Chile. The Las Encinas site was located inside a sports campus representing urban background concentrations that was not exposed to the direct emission sources in the area. The Padre Las Casas site was located in an urban area close to a residential zone being directly impacted by domestic biomass combustion emissions. The locations of the LE and PLC stations are shown in Fig. 1. Measurements were conducted during two seasons. Winter campaign was conducted from 4 to 24 July, 2019 (20 days) and 24 July to 7 August, 2019 (13 days) at the LE and the PLC sites, respectively (austral winter). Spring campaign measurements were conducted from 19 November to 10 December, 2019 (22 days) and 11 to 24 December, 2019 (12 days) at the LE and the PLC sites, respectively (austral spring).

Cities of Temuco and Padre Las Casas have been declared as saturated zones for $\mathrm{PM}_{2.5}$ by the Chilean environmental authorities (MMA, 2015), and together they form a portion of a conurbation area called Greater Temuco having 358541 inhabitants. In Temuco, services, tourisms, and agriculture are the main economic activities. Temuco has been ranked among the top five cities in Chile with severe air pollution problem (Díaz-Robles et al., 2014). According to the environmental public agency, $94 \%$ and $82 \%$ of $\mathrm{PM}_{2.5}$ and $\mathrm{PM}_{10}$ emissions, respectively, come from the residential wood combustion employed for cooking and heating (MMA, 2015).

\subsection{Meteorology}

Greater Temuco area is characterized by temperate rainy climate with the Mediterranean influence. The annual average temperature is approximately $12^{\circ} \mathrm{C}$ and rainfall close to $1000 \mathrm{~mm}$ per year. Fig. 2 shows the monthly variation for temperature, relative humidity, and rainfall in 2019 at the Manquehue Station (38 46'4.01"S, 72 $\left.37^{\prime} 54.98^{\prime \prime} \mathrm{W}\right)$, Temuco. The lowest temperatures occur from July to September together with the relative humidity above $80 \%$ (winter season) while from October to December temperatures are above $10^{\circ} \mathrm{C}$ and the humidity below $80 \%$ representing the spring and summer season. During winter, successive frontal disturbances generate a large part of the rainfall registered in this zone. In the spring and summer months, the rainfall is significantly lower, approximately $10 \mathrm{~mm}$ per month. In 2019, when the measurements were conducted, the total precipitation was $780 \mathrm{~mm}$ and the highest precipitations occurred 
between May and July with the total rainfall over $500 \mathrm{~mm}$. Between October and December the rainfall reached almost $80 \mathrm{~mm}$.

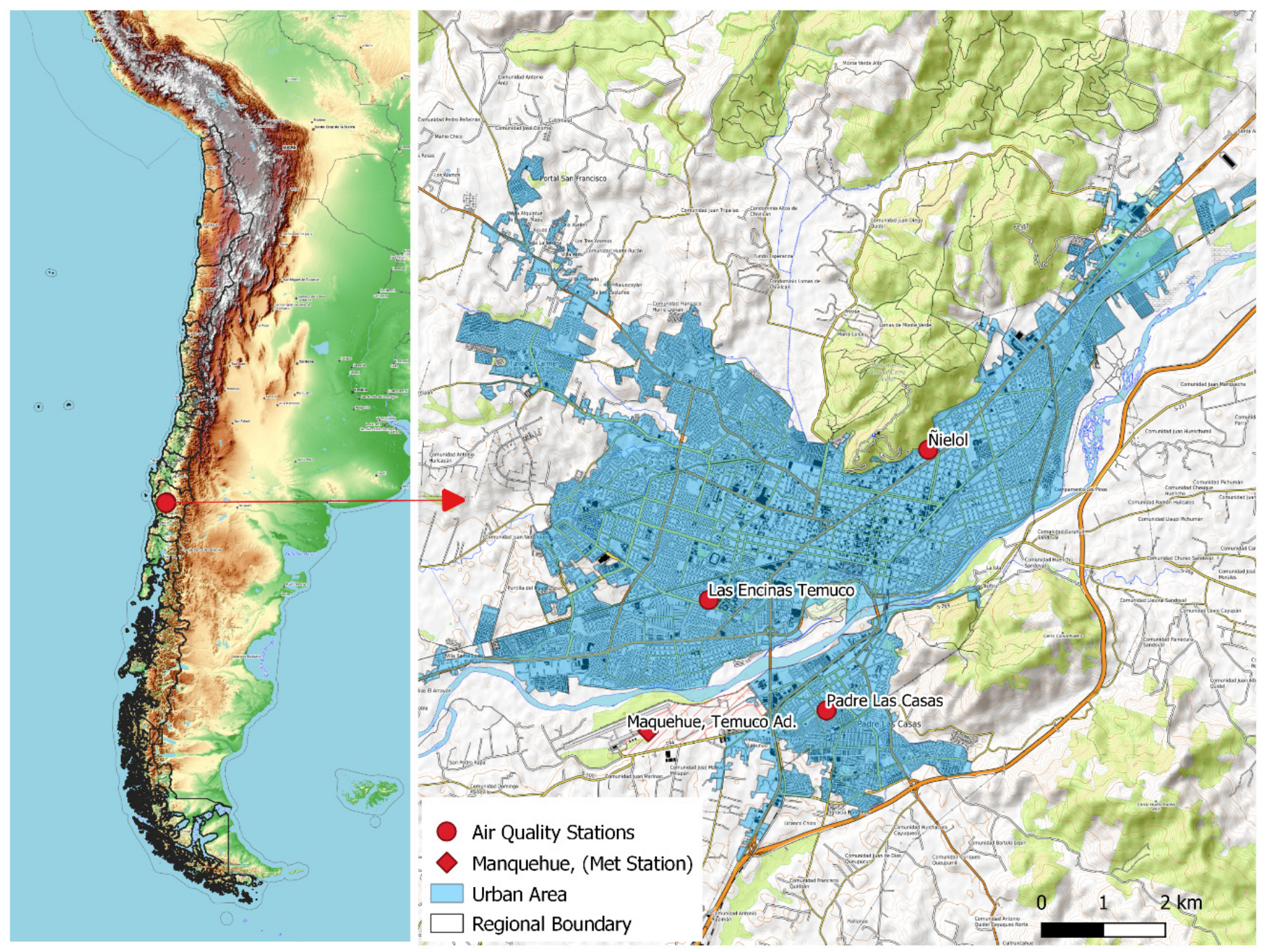

Fig. 1. Official Air Quality Network of Greater Temuco area. The locations of the air quality monitoring and meteorological sites are shown by the red dots (map extracted from Open Street Map service). Measurements presented in this article were conducted at the Las Encinas and Padre Las Casas stations.
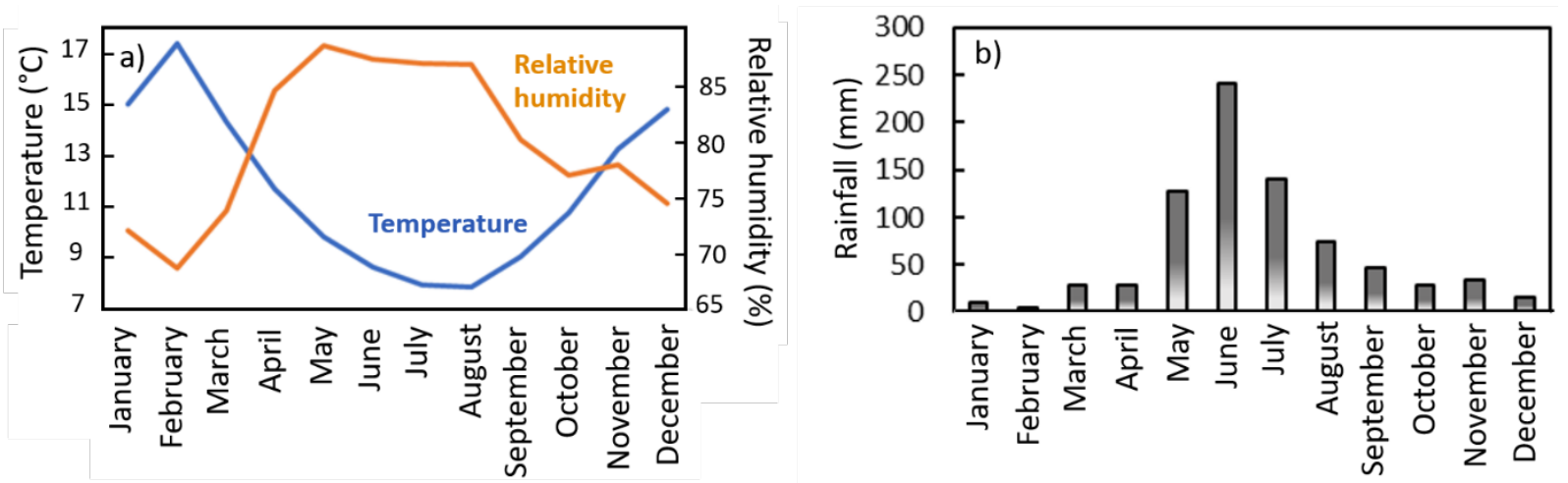

Fig. 2. Monthly average temperature and relative humidity (a), and rainfall (b) at the Manquehue station in Temuco in 2019. Data was extracted from the Dirección Meteorológica de Chile database that belongs to Chile's Meteorological Directorate (Servicios Climáticos; meteochile.gob.cl). 


\subsection{On-line Instrumentation}

An Aerosol Chemical Speciation Monitor (ACSM, Aerodyne Research Inc., US) was used to measure the main non-refractory chemical species (organics, sulphate, nitrate, ammonium, chloride) of submicron PM. The ACSM is a compact aerosol mass spectrometer with a quadruple detector described in detail by (Ng et al., 2011b). Shortly, a critical orifice and aerodynamic lens are used to guide the particle flow into the instrument and focus particles into a narrow beam. Due to the restrictions of the aerodynamic lens, the size-range of the particles transmitted to the ACSM is limited to submicron particles (100\% transmission approximately from $75 \mathrm{~nm}$ to $650 \mathrm{~nm}$ ). After the lens system, the particles are led to the vacuum chambers that are differentially pumped by three turbo pumps. The particles are vaporized with a tungsten oven $\left(600^{\circ} \mathrm{C}\right)$ and ionized $(70 \mathrm{eV})$ prior to leading them to the residual type of quadrupole mass analyzer. Time resolution of the measurements was 30 minutes with a default collection efficiency of 0.5 applied (Ng et al., 2011b).

A SIMCA (Gramsch et al., 2000) was used to determinate black carbon (BC) concentrations. The SIMCA (a Spanish name for the Absorption Coefficient Measurement System) was manufactured by Santiago University, and its operation is based on the variation of the integrating plate method (Horvath, 1997) to measure the absorption coefficient of light in the air (Gramsch et al., 2014b). The SIMCA contains a filter, two light-emitting diodes (LEDs), two photodetectors, an electronic amplifier, and a computer. The sample is pumped for $1 \mathrm{~min}$ through a 25 -mm-diameter Nuclepore filter that collects particles in the air, and the intensity of light passing through the filter is measured. The filter is exchanged by a new one once the light intensity of the sampled filter decreases to a value below $30 \%$ of the initial intensity (clean original filter) in order to avoid an excessive accumulation of light absorbing particles. A second detector, placed on the side of the filter, is utilized to correct for the changes in the lamp intensity or gain in the amplifier due to the temperature changes. The performance of the SIMCA has been validated in several previous studies (Gramsch et al., 2004, 2013, 2014b, 2016; Langner et al., 2020; Tagle et al., 2018).

$\mathrm{PM}_{2.5}, \mathrm{NO}_{\mathrm{x}}$ concentration and meteorological parameters were obtained from the official monitoring records (Padre Las Casas and Las Encinas stations). The hourly $\mathrm{PM}_{2.5}$ data were collected by a BAM-1020 Continuous Particulate Monitor, $\mathrm{NO}_{\mathrm{x}}$ data was recorded by a Thermo Monitor $42 \mathrm{i}$ and the meteorological data, including temperature, relative humidity, and wind speed, was recorded by LSI LASTEM (DMA765; Environmental Monitoring Solutions - LSI Lastem Soluzioni per il monitoraggio ambientale, Isi-lastem.com) instrumentations.

\subsection{Off-line Sampling and Analysis}

$\mathrm{PM}_{2.5}$ and $\mathrm{PM}_{10}$ samples were collected at the Las Encinas and Padre Las Casas sites during winter and spring campaigns. The 24-hour $\mathrm{PM}_{2.5}$ and $\mathrm{PM}_{10}$ samples were collected to $47 \mathrm{~mm}$ Polytetrafluoroethylene (PTFE) filters using two Harvard impactors (Marple and Willeke, 1976). The flow rate was $16.7 \mathrm{~L} \mathrm{~min}^{-1}$. The filter samples were weighed before and after the collections by using a Mettler UMT2 balance in a facility with a stable temperature $\left(20-22^{\circ} \mathrm{C}\right)$ and relative humidity (45-55\%). After the gravimetric analysis, the elemental composition was first analyzed by the energy dispersive $x$-ray fluorescence (XRF) analyzer, and then, the filters were split into two pieces for the subsequent ion and monosaccharide anhydride (MA) analysis.

A Panalytical Epsilon 5 XRF analyzer (Netherlands) was used for the elemental analysis of all $\mathrm{PM}_{10}$ and $\mathrm{PM}_{2.5}$ filter samples. The analyzed elements included $\mathrm{Al}, \mathrm{Ba}, \mathrm{Br}, \mathrm{Ca}, \mathrm{Ce}, \mathrm{Cl}, \mathrm{Cr}, \mathrm{Cs}, \mathrm{Cu}$, $\mathrm{Eu}, \mathrm{Fe}, \mathrm{K}, \mathrm{La}, \mathrm{Mg}, \mathrm{Na}, \mathrm{P}, \mathrm{Pb}, \mathrm{S}, \mathrm{Sc}, \mathrm{Sm}, \mathrm{Si}, \mathrm{Tb}, \mathrm{Ti}, \mathrm{W}$ and $\mathrm{Zn}$. The emissions of $\mathrm{x}$-ray photons from the sample are integrated over time and they yield quantitative measurements of elements ranging from sodium $(\mathrm{Na})$ through lead $(\mathrm{Pb})$. A spectrum of $\mathrm{X}$-ray counts versus photon energy is acquired during the analysis with individual peak energies corresponding to the elements and peak areas corresponding to the elemental concentrations. A sample spectrum consists of characteristic peaks superimposed on a background caused by the scatter of $x$-rays from the tube into the detector. The advantages of the XRF analysis include high sensitivity for several elements, the ability to analyze small quantities of sample, and the non-destructive nature of the analysis. Regarding the elemental composition of $\mathrm{PM}_{2.5}$, all the samples whose concentration value was less than or equal to their uncertainty were discarded. Only those elements that met at least $75 \%$ completeness were considered valid according to the methodology described by Kavouras et al. (2001). 
For the ion analysis, the $\mathrm{PM}_{2.5}$ filter samples were extracted with $10 \mathrm{~mL}$ of deionized water (Milli-Q, Millipore Gradient A10) by shaking the filters for 15 minutes. Two ICS-2000 ion chromatographs (IC, Dionex, Sunnyvale, USA) were used to measure anions $\left(\mathrm{Cl}^{-}, \mathrm{NO}_{3}{ }^{-}, \mathrm{SO}_{4}{ }^{2-}\right.$, oxalate) and cations ( $\mathrm{Na}^{+}$, $\left.\mathrm{NH}_{4}^{+}, \mathrm{K}^{+}, \mathrm{Mg}^{2+}, \mathrm{Ca}^{2+}\right)$. The IC-2000 systems had $4 \mathrm{~mm}$ AG11/CG12A guard columns, $4 \mathrm{~mm}$ AS11/CS12A analytical columns, $500 \mu \mathrm{L}$ loops, $4 \mathrm{~mm}$ AERS/CERS 500 suppressors and $\mathrm{KOH}$ and MSA eluent for the anions and cations, respectively. The uncertainty of the IC analysis of the filters was calculated based on the test samples and it was in the order of $10-15 \%$ for all the analyzed ions.

Monosaccharide anhydrides (i.e., levoglucosan, galactosan and mannosan) are water-soluble compounds that are commonly used as tracers for biomass burning since they are formed in the thermal breakdown of cellulose (Saarnio et al., 2012). High-performance anion-exchange chromatography-mass spectrometry (HPAEC-MS) method was used for the determination of levoglucosan, mannosan, and galactosan concentrations from the $\mathrm{PM}_{2.5}$ filter samples. The analytical method was similar as described in Saarnio et al. (2010) except that the internal standard was methyl- $\beta$-D-arabinopyranoside. MA's were extracted from the filter using $10 \mathrm{~mL}$ of deionized water (with internal standard $100 \mathrm{ng} \mathrm{mL}^{-1}$ ) by 15 min rotation. The HPAEC-MS system had $2 \mathrm{~mm}$ CarboPac ${ }^{\mathrm{TM}}$ PA10 guard and analytical columns (Dionex), $\mathrm{KOH}$ as an eluent, a $50 \mu \mathrm{L}$ loop and a $2 \mathrm{~mm}$ AERS Ultra II suppressor. Ionization technique was electron ionization and MS was equipped with a quadrupole mass analyzer. HPAEC-MS method uses $\mathrm{m} / \mathrm{z} 161$ for MA determination.

\subsection{Cluster Analysis and Heatmap}

Cluster Analysis (Gramsch et al., 2006) can be used as an exploratory statistical technique that seeks to reveal natural groupings in a data set. In this article, the purpose of applying cluster analysis is the segmentation of pollutant variables to a certain source, especially to identify the pollutants originating from biomass burning. It is a non-supervised technique used to identify relatively homogenous groups called clusters. The cluster must show a high degree of internal homogeneity (within the conglomerate) and a high degree of external heterogeneity (between clusters). The concept of similarity is fundamental to the analysis of conglomerates. A measure of similarity is a measure of correspondence or resemblance between objects to be grouped. Similarity can be measured in several ways, but there are three methods that are used in cluster analysis: correlation, distance, and association. These methods do not distinguish between variables dependent and independent.

Analysis of the elements and monosaccharide compounds (galactosan, levoglucosan, and mannosan) was processed as follows. Daily concentrations were considered valid if the value surpassed its associated uncertainty. For each valid daily concentration, the contribution of each element to $\mathrm{PM}_{2.5}$ was calculated ([element]/[PM 2.5$]$ ). Only those elements and chemical compounds with $75 \%$ or more valid daily data were included in the analysis. Median and standard deviation of daily contribution values for each element and chemical compound for all sites (Padre Las Casas and Las Encinas) and seasons (winter and spring) were calculated. Raw-Z score was calculated for each day as the number of standard deviations from the median. Values higher than the median were reported as positive in red while values below the median were reported as negative in green. Average linkage clustering method and Euclidean distances were employed to develop hierarchical clustering using the online visualization tool Heatmapper (Babicki et al., 2016).

\section{RESULTS AND DISCUSSION}

\subsection{On-line PM Concentrations and Chemical Composition}

PM mass concentrations and the chemical composition of submicron PM were measured at the Las Encinas (LE) and Padre Las Casas (PLC) sites during winter and spring. The average $\mathrm{PM}_{2.5}$ concentration was higher at the urban-residential site (PLC) than at the urban background site (LE) in the wintertime (Table 1). It should be noted that the measurements were not conducted simultaneously at LE and PLC but the campaign at PLC was started immediately after that at LE and therefore they are assumed to the represent similar meteorological conditions. Comparison between the periods shown in supplemental material (Figs. S1-S4, Table 1). Compared to the earlier measurements in urban areas in Chile, both sites exhibited at wintertime $\mathrm{PM}_{2.5}$ levels 
Table 1. One hour average $\mathrm{PM}_{2.5}$ and submicron organics, chloride, ammonium, nitrate, sulphate and $\mathrm{BC}$ concentrations observed at the measurement sites (Las Encinas, Padre las Casas) during spring and winter campaigns measured with the online instruments (ACSM and SIMCA).

\begin{tabular}{|c|c|c|c|c|}
\hline \multirow{2}{*}{$\begin{array}{l}\text { Mass concentration } \\
\left(\mu \mathrm{g} \mathrm{m}^{-3}\right)\end{array}$} & \multicolumn{2}{|c|}{ Las Encinas (LE) } & \multicolumn{2}{|c|}{ Padre Las Casas (PLC) } \\
\hline & Winter (4-24 Jul) & Spring (19 Nov-10 Dec) & Winter (24 Jul-7 Aug) & Spring (11 Nov-24 Dec) \\
\hline $\mathrm{PM}_{2.5}$ (continuous) & 38.4 & 6.8 & 85.0 & 6.3 \\
\hline Organics & 30.5 & 3.53 & 62.02 & 2.77 \\
\hline Chloride & 0.87 & 0.09 & 1.61 & 0.08 \\
\hline Ammonium & 0.62 & 0.37 & 1.26 & 0.34 \\
\hline Nitrate & 1.61 & 0.28 & 2.73 & 0.22 \\
\hline Sulphate & 0.51 & 0.86 & 1.07 & 0.83 \\
\hline $\mathrm{BC}$ & 1.17 & 0.64 & 2.44 & 0.66 \\
\hline
\end{tabular}

higher than those reported in Santiago during winter (48 $\mu \mathrm{g} \mathrm{m}^{-3}$ (Tagle et al., 2018); $30 \mu \mathrm{g} \mathrm{m}^{-3}$ (Carbone et al., 2013)). The differences between $\mathrm{PM}_{10}$ levels in Temuco and Santiago have also been reported previously by Diaz-Robles et al. (2014, 2015). Temuco is classified as one of the most polluted cities in Latin America by the World Health Organization (Díaz-Robles et al., 2015). These cities show also clear differences between the emissions sources: the main source of PM in Temuco is wood burning while in Santiago emissions originate mostly from mobile sources with a high contribution of secondary particles (Tagle et al., 2018; Carbone et al., 2013). This information likely explains at least partly the differences in PM levels between Santiago and Temuco.

On the other hand, the peak hourly $\mathrm{PM}_{2.5}$ concentrations (up to $700 \mu \mathrm{g} \mathrm{m}^{-3}$ ) measured at Las Encinas and Padre Las Casas are comparable to the concentrations typically observed in the world's most polluted cities (Gani et al., 2019; Huang et al., 2010). In the springtime, significantly lower average $\mathrm{PM}_{2.5}$ concentrations (PLC $6.3 \mu \mathrm{g} \mathrm{m}^{-3}$, LE $6.8 \mu \mathrm{g} \mathrm{m}^{-3}$ ) were measured. In spring, the $\mathrm{PM}_{2.5}$ concentrations at Las Encinas and Padre Las Casas were comparable to those reported elsewhere in the world (Lorelei de Jesus et al., 2020). In terms of chemical species, the average concentrations of organics, inorganic compounds (nitrate, sulphate, ammonium, and chloride) and $\mathrm{BC}$ were similar at both sites in spring, however, in winter the concentrations at Padre Las Casas were double the values observed at Las Encinas. In general, the concentrations were significantly higher in winter for all the compounds at both sites, except for sulphate at Las Encinas (Table 1).

Figs. 3 and 4. show the time series for the concentrations of the main chemical components of submicron particles i.e., organics, BC, nitrate, sulphate, ammonium and chloride measured by the ACSM and SIMCA whereas Figs. 5 and 6. show the corresponding mass fractions of the chemical components at both sites in spring and winter, respectively. The sum of the main chemical components in submicron particles follows the time trend of the $\mathrm{PM}_{2.5}$ concentration (Pearson $r$ $=0.82$ and $r=0.48$ for winter and spring, respectively) at both stations. In the springtime, the variation in the measured concentrations was smaller (between 5-35 $\mu \mathrm{g} \mathrm{m}^{-3}$ ), whereas in winter, a number of large spikes for the $\mathrm{PM}_{2.5}$ concentrations between 200 and $700 \mu \mathrm{g} \mathrm{m}^{-3}$ were observed. Higher Pearson correlation values in winter compared to the spring campaign can be related to the changes in the strengths of the predominant emission sources. PM 2.5 concentrations in winter were 5.6-13.5 times higher than those reported during the spring campaign. Winter/spring difference was especially large at the PLC station. Regarding chemical composition, organics and chloride shows the biggest changes among the season, mostly related to wood burning. Based on the high Pearson correlation in the winter campaign, it can be assumed that the temporal variation of $\mathrm{PM}_{2.5}$ in winter is mainly due to wood combustion sources. In the springtime, the strength of these emission sources decreased significantly because of lower demand for heating. Therefore, in spring, other $\mathrm{PM}_{2.5}$ sources were more important, like dust components, which are not measured by real time instrumentation used here (because dust is mostly refractory material, i.e., carbonates). The increase of the relative contribution of refractory material in $\mathrm{PM}_{2.5}$ could also explain the lower person coefficient recorded in the spring campaign.

Submicron particle mass was dominated by organic compounds in winter and spring periods. During spring, the average contribution of organics was 61 and $57 \%$ of the total analyzed mass 


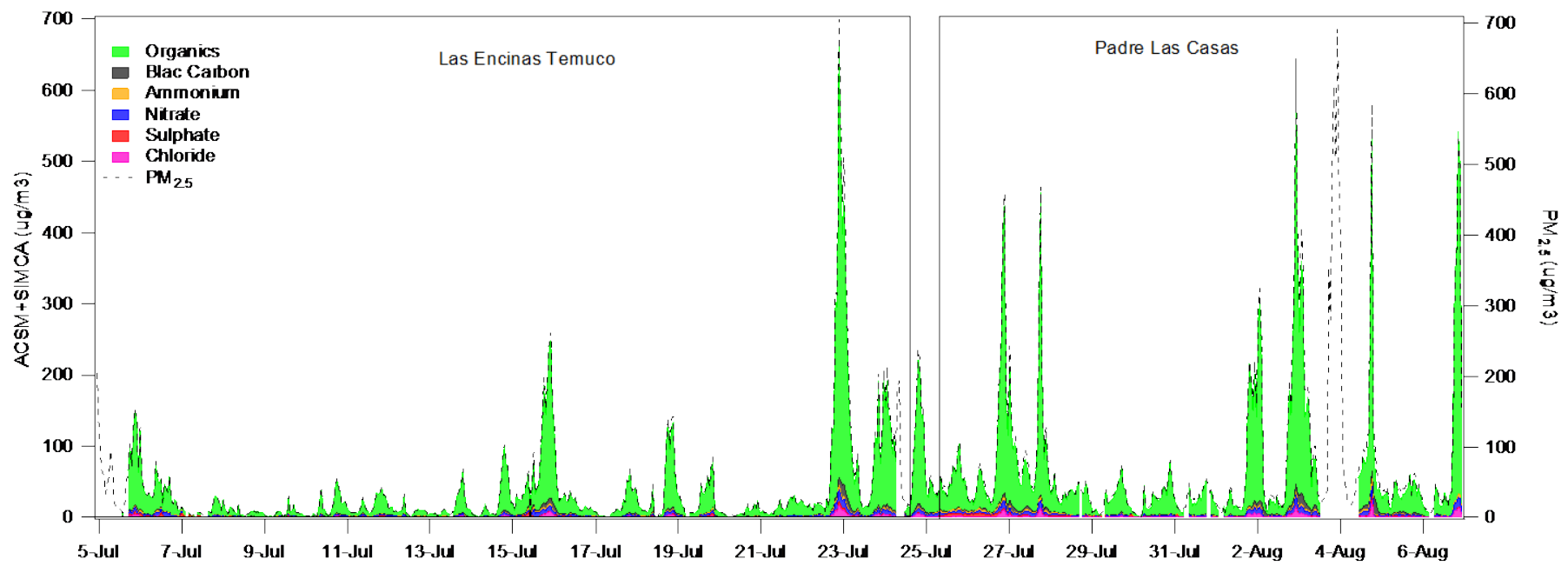

Fig. 3. The timeseries of submicron organics, nitrate $\left(\mathrm{NO}_{3}{ }^{-}\right)$, sulphate $\left(\mathrm{SO}_{4}{ }^{2-}\right)$, ammonium $\left(\mathrm{NH}_{4}{ }^{+}\right)$and chloride $\left(\mathrm{Cl}^{-}\right)$measured with the ACSM, BC measured with the SIMCA and PM2.5 concentration measured with the BAM-1020 at Las Encinas Temuco and Padre las Casas in winter.

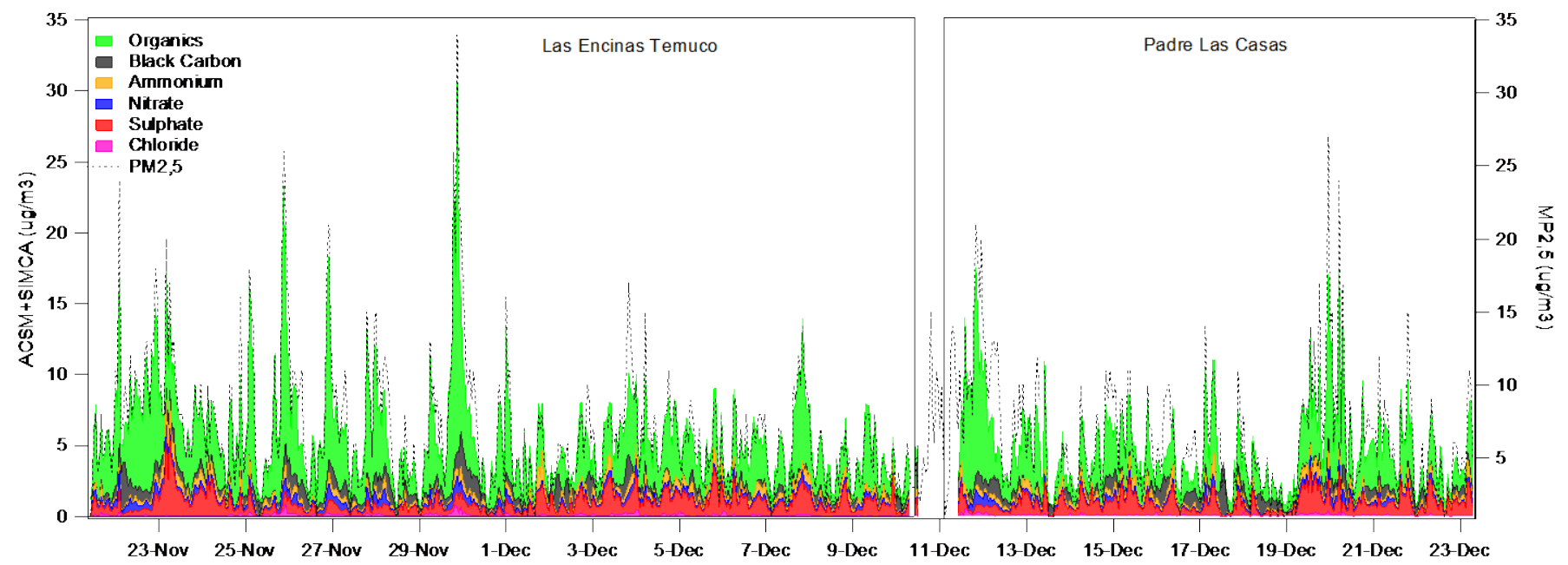

Fig. 4. The timeseries of submicron organics (Org), nitrate $\left(\mathrm{NO}_{3}{ }^{-}\right)$, sulphate $\left(\mathrm{SO}_{4}{ }^{2-}\right)$, ammonium $\left(\mathrm{NH}_{4}{ }^{+}\right)$and chloride $\left(\mathrm{Cl}^{-}\right)$measured with the ACSM, BC measured with the SIMCA and PM 2.5 concentration measured with the BAM-1020 at Las Encinas Temuco and Padre las Casas in spring.

at Las Encinas and Padre Las Casas, respectively, whereas during winter, the average contribution of organics was larger reaching 86 and $87 \%$ at Las Encinas and Padre Las Casas, respectively. The average contribution of inorganic ions was 28 and $30 \%$ during spring, and it decreased to 10 and 9\% during winter at Las Encinas and Padre Las Casas, respectively. Similarly, the BC contribution was smaller during winter (3.3 and 3.4\%) than during spring (11 and 13\%) at Las Encinas and Padre Las Casas, respectively. It should be noted that the mass fraction (Fig. 5) does not change substantially between the sites, indicating that the average chemical composition reflects a rather regional influence. However, the contribution of inorganic ions and $B C$ was significantly smaller in the winter season whereas the concentrations of organics was larger. In-depth analysis of inorganic compounds is presented in a later section. The higher concentrations of $B C$ found at Padre Las Casas were mainly attributed to the impact of local emissions from the sources located in the surroundings of the station, especially residential biomass burning (discussed later).

The composition of submicron PM with prevailing organic fraction, relatively large inorganic fraction (9-30\%) and a small fraction of $\mathrm{BC}(<13 \%)$ was similar to the composition observed in the polluted areas in Asia (Gani et al., 2019; Huang et al., 2019). In a study conducted in India 


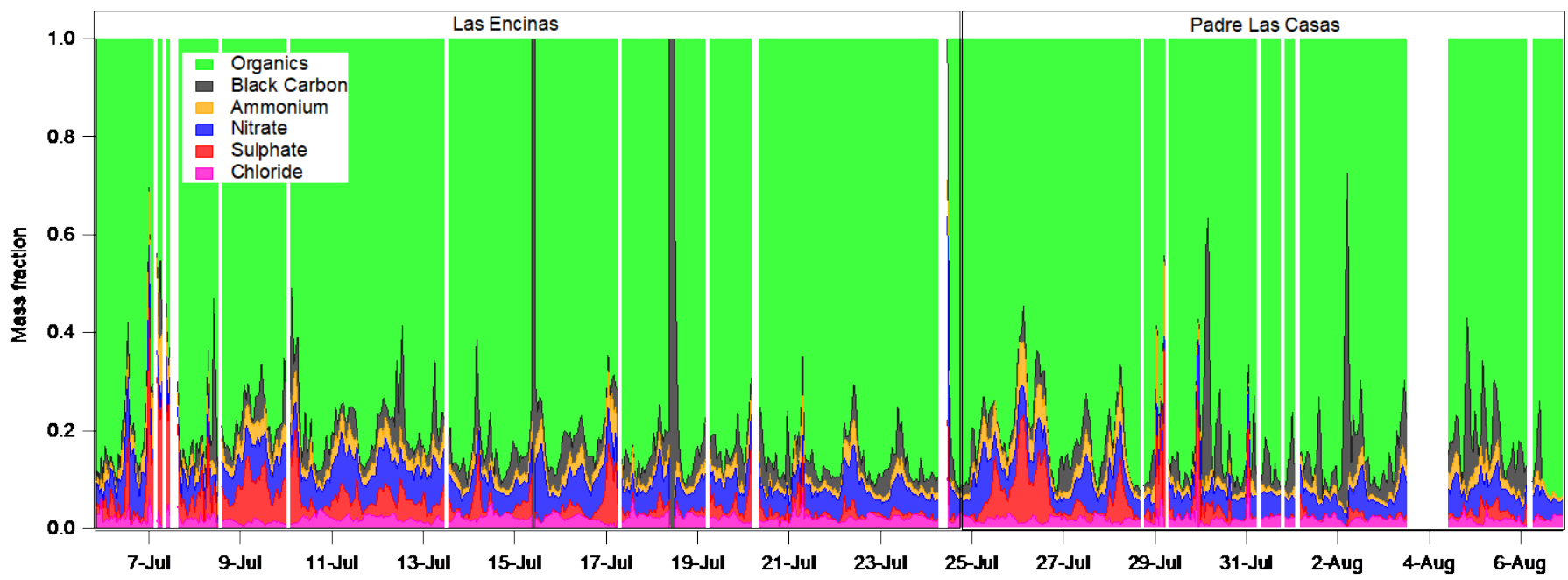

Fig. 5. Mass fractions of submicron organics, nitrate $\left(\mathrm{NO}_{3}{ }^{-}\right)$, sulphate $\left(\mathrm{SO}_{4}{ }^{2-}\right)$, ammonium $\left(\mathrm{NH}_{4}{ }^{+}\right)$and chloride $\left(\mathrm{Cl}^{-}\right)$measured with the ACSM and BC measured with the SIMCA at Las Encinas Temuco and Padre las Casas in winter.

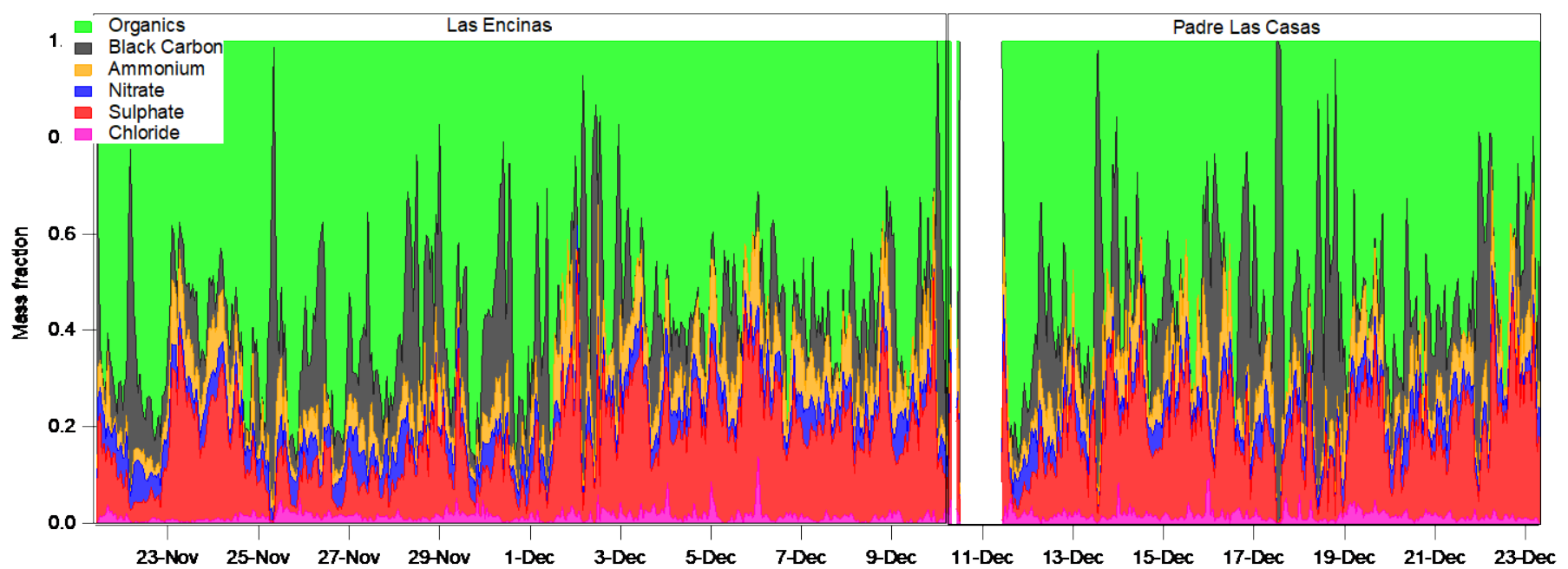

Fig. 6. Mass fractions of submicron organics, nitrate $\left(\mathrm{NO}_{3}{ }^{-}\right)$, sulphate $\left(\mathrm{SO}_{4}{ }^{2-}\right)$, ammonium $\left(\mathrm{NH}_{4}{ }^{+}\right)$and chloride $\left(\mathrm{Cl}^{-}\right)$measured with the ACSM and BC measured with the SIMCA at Las Encinas Temuco and Padre las Casas in spring.

(Gani et al., 2019), they found a BC contribution of only 5\%, and in another study conducted in Beijing, the BC contribution reached 3.1\% (Huang et al. 2010), similar to the BC contribution obtained in this study.

\subsection{Diurnal Variation of PM and Chemical Components}

Fig. 7 shows the average diurnal variation for organics, BC, sulphate, nitrate, ammonium, and chloride at both sites, LE and PLC, in the winter and spring seasons. The data from both sites were combined. In the wintertime, the compounds measured by the ACSM increased in the morning between 08:00 and 10:00 AM, and again at the evening between 4:00 and 10:00 PM, except sulphate which had no clear diurnal trend. Besides that, for nitrate, ammonium, organics and chloride a third (small) peak was observed at 11:00 AM that was probably associated with photochemical activity and the formation of secondary ammonium nitrate (Wang et al., 2015).

Fig. 8 shows the average diurnal profiles for $\mathrm{NO}_{x}$ measured at the PLC station. $\mathrm{NO}$ and $\mathrm{NO}_{2}$ had similar diurnal trends to organics and chloride (Fig. 7), although they were peaking approximately one hour later. The evening peaks for the chemical species (excluding sulphate) and $\mathrm{NO}_{x}$ were dominating over the morning peaks. In the springtime, the diurnal profile for the species was not 

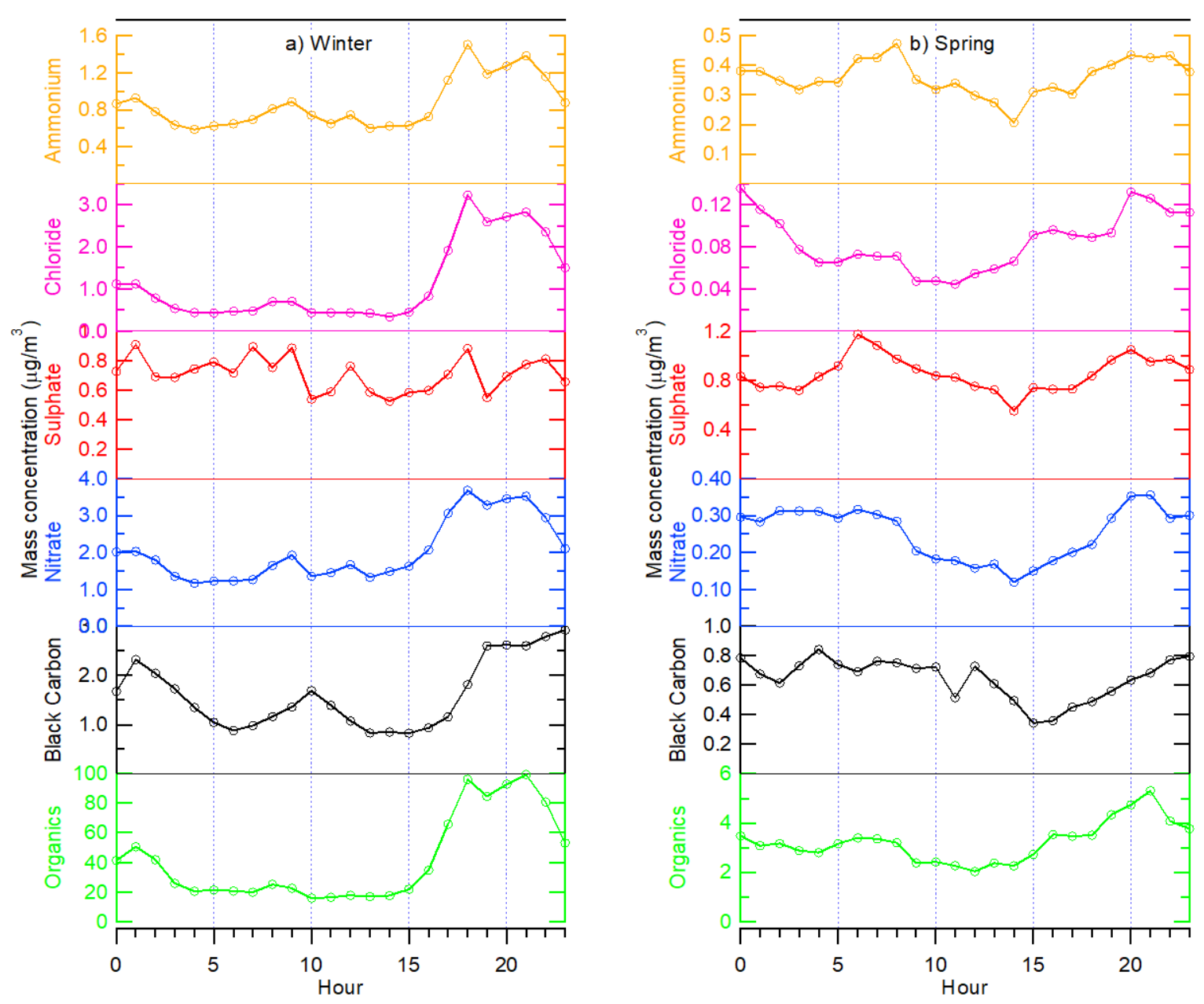

Fig.7. Average diurnal variation of the main particulate chemical species in the winter (a) and spring (b) campaign.

so profound. Lowest concentrations for the species were measured typically during the midday and relatively higher concentrations during nights indicating poor mixing during the night.

The diurnal profile for the $\mathrm{NO}_{2} / \mathrm{NO}_{x}$ ratio at the Padre Las Casas station shows a clear decrease during the rush-hour in the spring morning indicating a clear impact from traffic emissions at that time of the day. $\mathrm{NO}_{2} / \mathrm{NO}_{\mathrm{x}}$ ratio values between 0.1 and 0.3 have been reported for biomass burning emissions while significantly lower values have been attributed to the vehicle exhaust emissions (Burling et al., 2010; Yokelson et al., 1996). Rapid conversion from $\mathrm{NO}$ to $\mathrm{NO}_{2}$ can also be affecting the $\mathrm{NO}_{2} / \mathrm{NO}_{x}$ ratio, which can be in seconds scale under normal conditions ( 1 atm, $298 \mathrm{~K}, 50 \mathrm{ppbv}_{3}$ ) due to the $\mathrm{NO}$ reaction with $\mathrm{O}_{3}$ that increases the $\mathrm{NO}_{2} / \mathrm{NOx}$ ratio (Wild et al., 2017). Probably, the $\mathrm{NO}_{2} / \mathrm{NO}_{x}$ increase is also reflecting the ozone production during afternoon hours.

To explore the day-to-night variation in more detail, Table 2 shows the average concentrations of organics, sulphate, ammonium, nitrate, chloride, BC, and the meteorological data during day (average between $7 \mathrm{AM}$ and $7 \mathrm{PM}$ ) and night (average between $7 \mathrm{PM}$ and $7 \mathrm{AM}$ ) in Temuco in winter and spring. In the wintertime, the daytime concentration was significantly lower than the nighttime averages. High concentrations in winter nights were observed for all the analyzed components (Table 2). For instance, the concentrations of organics were 25 and 9 times higher during the winter nights than the average concentrations during the spring nights in Padre las Casas and Las Encinas, respectively. Low temperatures in winter increased the need for heating the homes, especially at night, which likely caused an increase in pollutant levels. However, temperatures were not that different between the day and night in winter which indicates that the boundary layer depth had a stronger influence than temperature changes. This trend may also be due to the fact that during the night people stay in their homes, after returning from work 


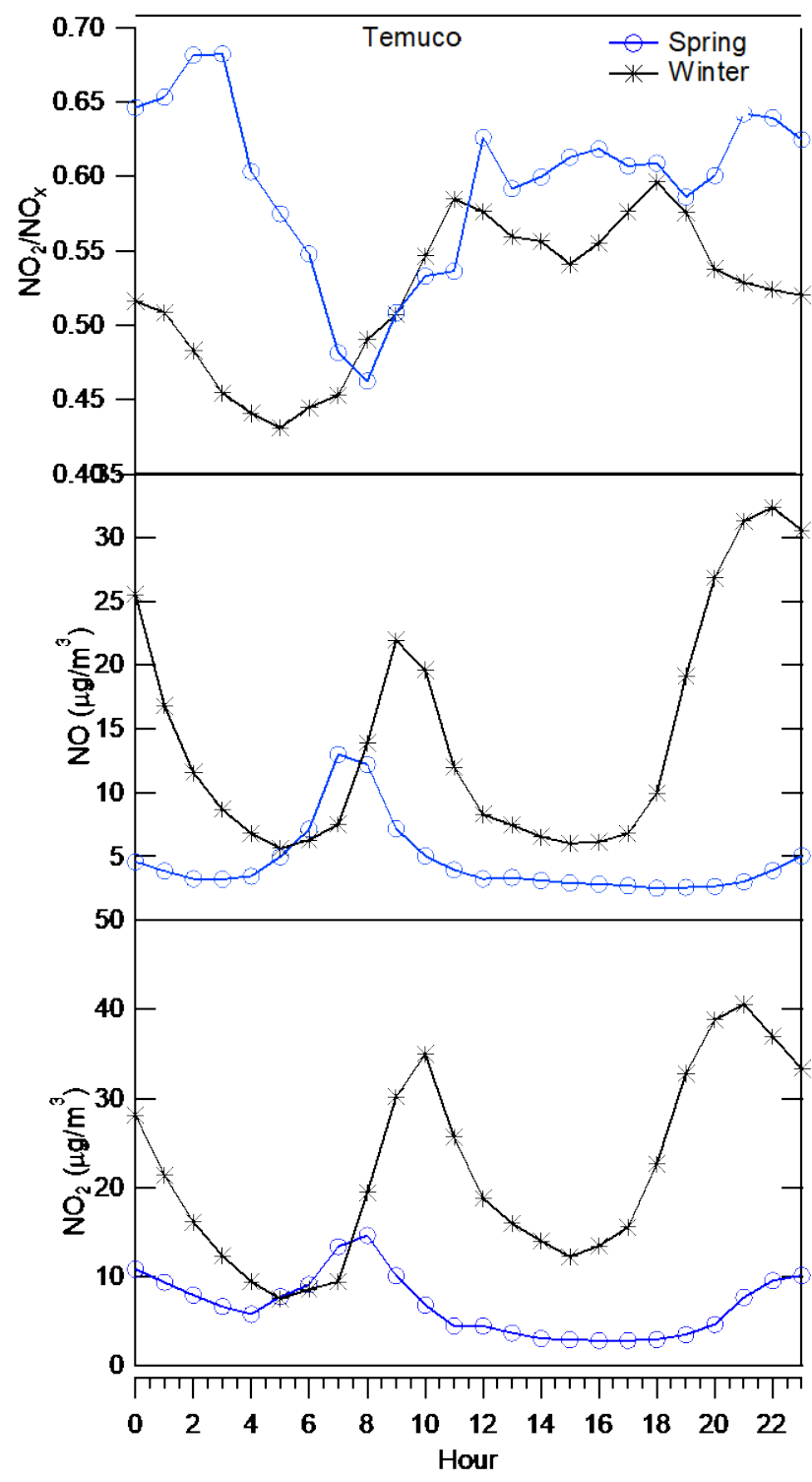

Fig. 8. Diurnal variation of $\mathrm{NO}_{2}$ (lowest panel), $\mathrm{NO}$, (middle panel), and $\mathrm{NO}_{2} / \mathrm{NO}_{\mathrm{x}}$ ratio (upper panel) in Temuco in winter (asterisk) and spring (circle).

Table 2. Average concentrations of organics, chloride, ammonium, nitrate, sulphate, $\mathrm{BC}, \mathrm{PM}_{2.5}$, temperature, relative humidity, and wind speed during day (7 AM-7 PM) and night (7 PM-7 AM) in the winter and spring campaigns at both stations (LE and $\mathrm{PLC})$. LE station has no $\mathrm{RH}$ records for the measurement period.

\begin{tabular}{|c|c|c|c|c|c|c|c|c|}
\hline \multirow{2}{*}{$\begin{array}{l}\text { Measured } \\
\text { parameter/time }\end{array}$} & \multicolumn{4}{|c|}{ Padre las Casas } & \multicolumn{4}{|c|}{ Las Encinas } \\
\hline & $\begin{array}{l}\text { Winter } \\
\text { Day }\end{array}$ & $\begin{array}{l}\text { Winter } \\
\text { Night }\end{array}$ & $\begin{array}{l}\text { Spring } \\
\text { Day }\end{array}$ & $\begin{array}{l}\text { Spring } \\
\text { Night }\end{array}$ & $\begin{array}{l}\text { Winter } \\
\text { Day }\end{array}$ & $\begin{array}{l}\text { Winter } \\
\text { Night }\end{array}$ & $\begin{array}{l}\text { Spring } \\
\text { Day }\end{array}$ & $\begin{array}{l}\text { Spring } \\
\text { Night }\end{array}$ \\
\hline Organics $\left(\mu \mathrm{g} \mathrm{m}^{-3}\right)$ & 10.88 & 22.21 & 0.78 & 0.87 & 6.99 & 16.57 & 1.39 & 1.76 \\
\hline Chloride $\left(\mu \mathrm{g} \mathrm{m}^{-3}\right)$ & 0.30 & 0.57 & 0.02 & 0.03 & 0.20 & 0.47 & 0.03 & 0.04 \\
\hline Amonium ( $\mu \mathrm{g} \mathrm{m}^{-3}$ ) & 0.29 & 0.35 & 0.08 & 0.09 & 0.19 & 0.27 & 0.12 & 0.15 \\
\hline Nitrate $\left(\mu \mathrm{g} \mathrm{m}^{-3}\right)$ & 0.60 & 0.83 & 0.06 & 0.07 & 0.53 & 0.71 & 0.09 & 0.15 \\
\hline Sulphate $\left(\mu \mathrm{g} \mathrm{m}^{-3}\right)$ & 0.21 & 0.24 & 0.20 & 0.22 & 0.15 & 0.21 & 0.29 & 0.35 \\
\hline Black Carbon $\left(\mu \mathrm{g} \mathrm{m}^{-3}\right)$ & 1.88 & 4.13 & 0.46 & 0.64 & 0.81 & 1.53 & 0.50 & 0.66 \\
\hline $\mathrm{PM}_{2.5}\left(\mu \mathrm{g} \mathrm{m}^{-3}\right)$ & 63.40 & 107.58 & 5.44 & 7.15 & 26.14 & 50.96 & 5.87 & 7.78 \\
\hline Temperature $\left({ }^{\circ} \mathrm{C}\right)$ & 9.15 & 7.63 & 17.56 & 12.64 & 9.20 & 7.08 & 17.35 & 12.10 \\
\hline Relative humidity (\%) & 82.41 & 89.85 & 60.97 & 80.03 & - & - & - & - \\
\hline Wind speed $\left(\mathrm{m} \mathrm{s}^{-1}\right)$ & 1.79 & 1.22 & 1.90 & 0.93 & 2.03 & 1.51 & 2.42 & 1.27 \\
\hline
\end{tabular}


and educational places, so there is a need to keep the houses warm. Besides more intensive sources in nighttime, it can be observed from the meteorological data that Padre Las Casas had the most unfavorable mixing conditions at night due to the low wind speed, high relative humidity, and low temperature. In the case of Las Encinas, higher wind speed during the day favored an increased aerosol dispersion.

\subsection{Influence of Biomass Burning and Local Meteorology during Pollution \\ Episodes}

The contribution of biomass combustion to the organic fraction and the aging of organic compounds were estimated based on the ACSM tracers' signals. The fraction $\mathrm{f}_{44}\left(f_{44}=\frac{\mathrm{m} / z=44}{O A}\right)$ was used as a tracer for secondary organic aerosol (SOA) (Jimenez et al., 2009; Ng et al., 2011a) and $f_{60}\left(f_{60}=\frac{m / z=60}{O A}\right)$ as a tracer for primary organic aerosol (POA) emitted by biomass burning (Cubison et al., 2011; Ortega et al., 2013).

A $\mathrm{f}_{44}$ vs. $\mathrm{f}_{60}$ scatter plot proposed by (Cubison et al., 2011) was created using the combined data from both sites (Las Encinas and Padre Las Casas), separately for the winter and spring campaign (Fig. 9 and Fig. 10, respectively). These graphs reveal the impact of biomass burning as a function of the level of atmospheric oxidation. Higher $\mathrm{f}_{44}$ values indicate strongly oxidized OA. Size and color of the points are proportional to the $\mathrm{PM}_{2.5}$ concentration and ambient temperature, respectively. In the wintertime, the $\mathrm{f}_{44}$ values measured at the Las Encinas and Padre Las Casas stations indicate that the OA oxidation reached an intermediate state with most of the $\mathrm{f}_{44}$ values in the region of $0.05<\mathrm{f}_{44}<0.13-0.15$, like typically observed for semi-volatile oxygenated organic aerosol (SV-OOA) (Ng, et al., 2011). A strong biomass burning impact was observed in the winter campaign since the $f_{60}$ values were significantly higher than the background values. By the size and color of the points (Fig. 9), the higher $\mathrm{PM}_{2.5}$ concentrations and lower temperatures are located at larger $\mathrm{f}_{60}$ values indicating that high $\mathrm{PM}_{2.5}$ concentrations were mostly related to POA

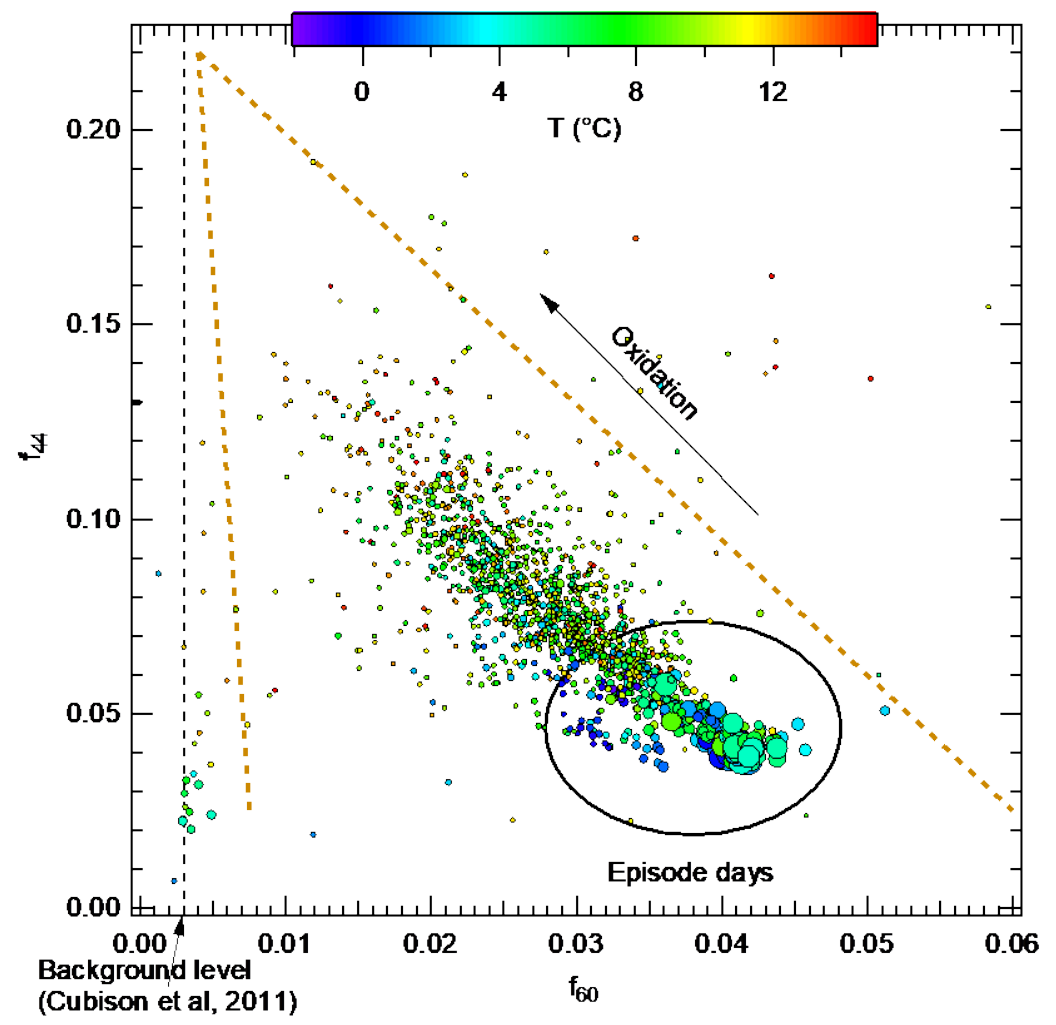

Fig. 9. Scatter graph of $f_{44}$ vs. $f_{60}$ for the winter campaigns at Las Encinas and Padre las Casas. The sizes of the points are proportional to the $\mathrm{PM}_{2.5}$ concentration. 


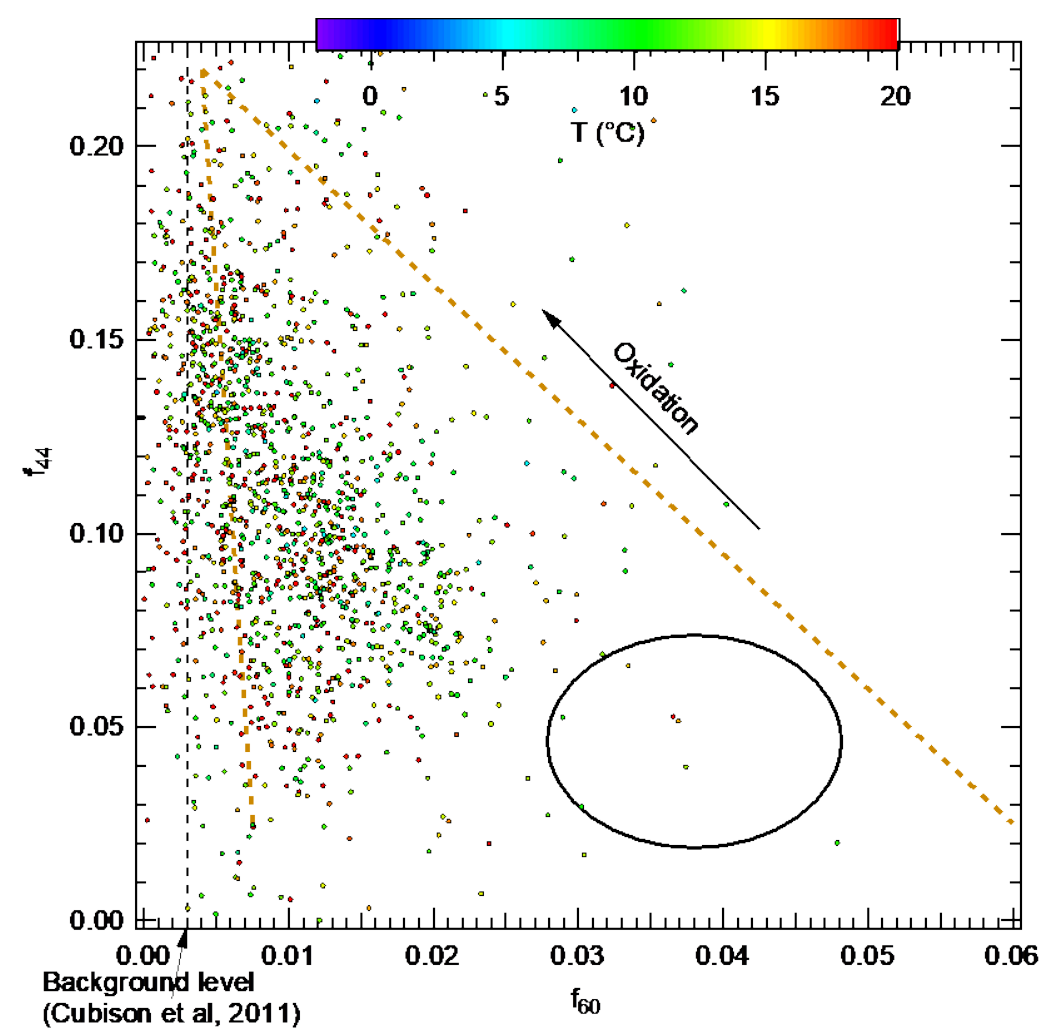

Fig. 10. Scatter graph of $\mathrm{f}_{44}$ Vs. $\mathrm{f}_{60}$ for the spring campaigns in Las Encinas and Padre las Casas. The sizes of the points are proportional to the $\mathrm{PM}_{2.5}$ concentration.

coming from the biomass burning emissions. Since atmospheric stability and thermal inversion at very low altitudes predominate during the episodes with the high $\mathrm{PM}_{2.5}$ concentration, it can be concluded that local biomass burning emissions contribute significantly to the observed $\mathrm{PM}_{2.5}$ mass during the episodes. The observed $f_{44}$ and $f_{60}$ values were increased and reduced respectively during the spring campaign when compared to the winter campaign. However, $f_{60}$ levels remained above the reference level also in spring indicating that the firewood combustion emissions from non-heating purposes probably impact the air quality during spring.

Meteorological conditions are the most important factors determining the impact of biomass burning on air quality at both monitoring sites. Gramsch et al. (2014a) argue that in Chile the days with high pollution typically present the following characteristics: (1) clear sky, (2) low wind speed, (3) large temperature variation during the day, and (4) frequent surface thermal inversion at night and early in the morning that further restricts the vertical air movements. In this study, different meteorological parameters for the winter and spring campaigns were compared, among them, precipitation levels, pressure, wind speed, surface temperature $(10 \mathrm{~m})$, and temperature registered at $344 \mathrm{~m}$, to analyze the trend and to define a criterion for the identification of these high concentration events. Mehmood et al. (2020) have presented model results how surface weather patterns influence on the temporal and spatial variation of $\mathrm{PM}_{2.5}$ concentrations over central and eastern China.

During the winter campaign, several pollution episodes with elevated PM concentrations were observed (Fig. 11). Most of these events (4-5, 14-16, 18-19 and 22-25 July, 2019 in Las Encinas, and 27-28 July and 2-6 August, 2019 in Padre las Casas) were characterized by the periods with high surface pressure, low temperatures, and low wind speed (marked with orange areas in Fig. 11). Also, the events matched with higher temperatures at high altitude than in the surface, identifying the typical profile of a vertical inversion. Additionally, these days had a high variation in day-to-night temperature, indicating frequent radiative thermal inversions in the Temuco region. As shown previously in Fig. 4, during the high pollution events (in the winter campaign), the concentrations of all the chemical species were observed to significantly increase and the organic fraction was prevailing. During the spring season (Fig. 12), no significant episode periods 
were identified. Therefore, it is possible to conclude that the nights with the highest levels of airpollution were determined both by the increased biomass combustion due to cold temperatures and by the meteorological conditions that hinder the dispersion of pollutants (lower temperatures, development of very low altitude thermal inversions, and low wind speeds), which enhance the impact of local emissions at the Las Encinas and Padre las Casas sites.

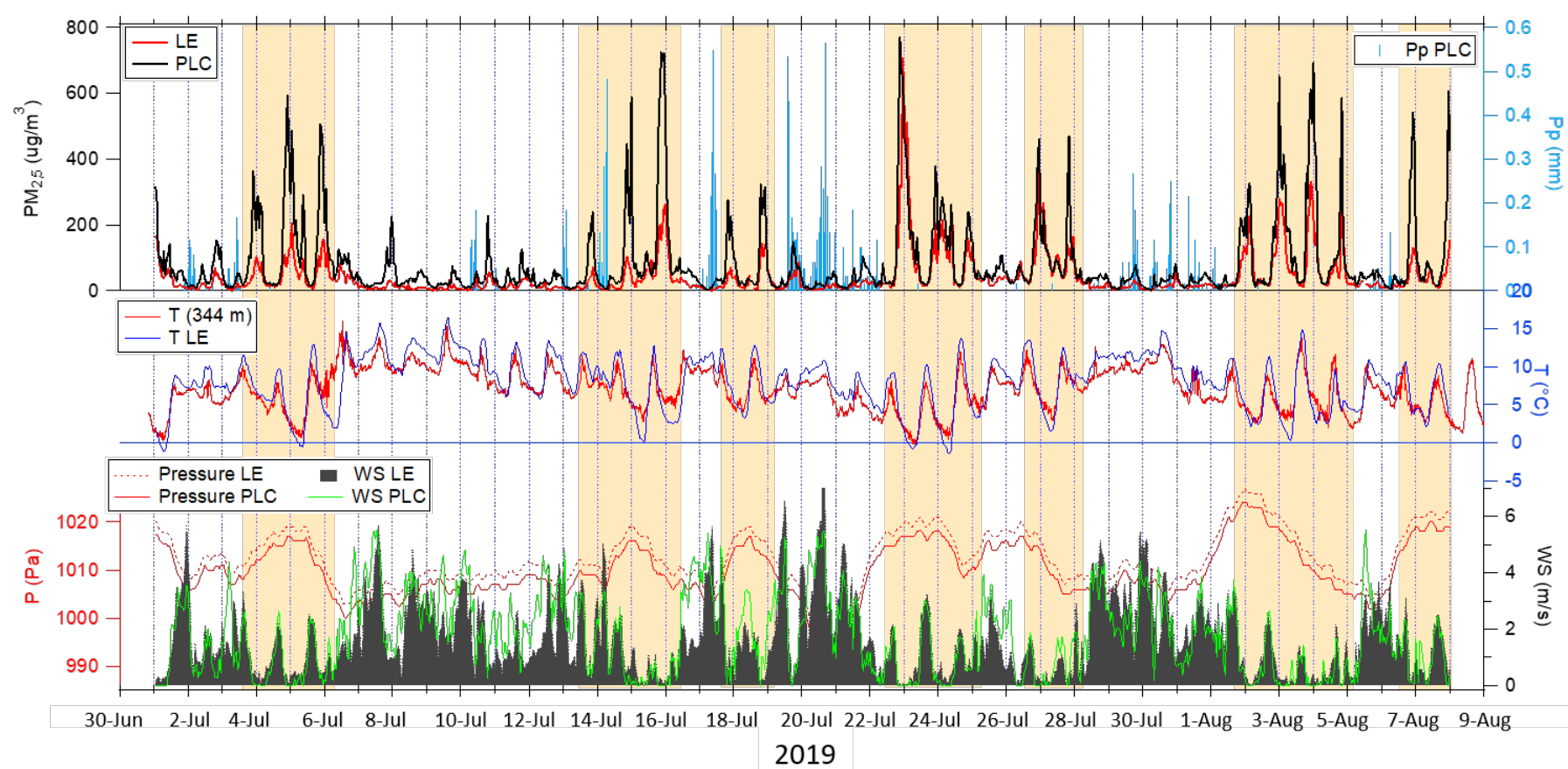

Fig. 11. Time series of $\mathrm{PM}_{2.5}$ concentration and meteorological parameters for the winter campaign in 2019. Periods with the high concentration events (episode days) are qualitatively illustrated in orange areas. LE: Las Encinas station. PLC: Padre Las Casas station. P: Ambient pressure. WS: Wind speed. T: Temperature. Pp: Precipitation.
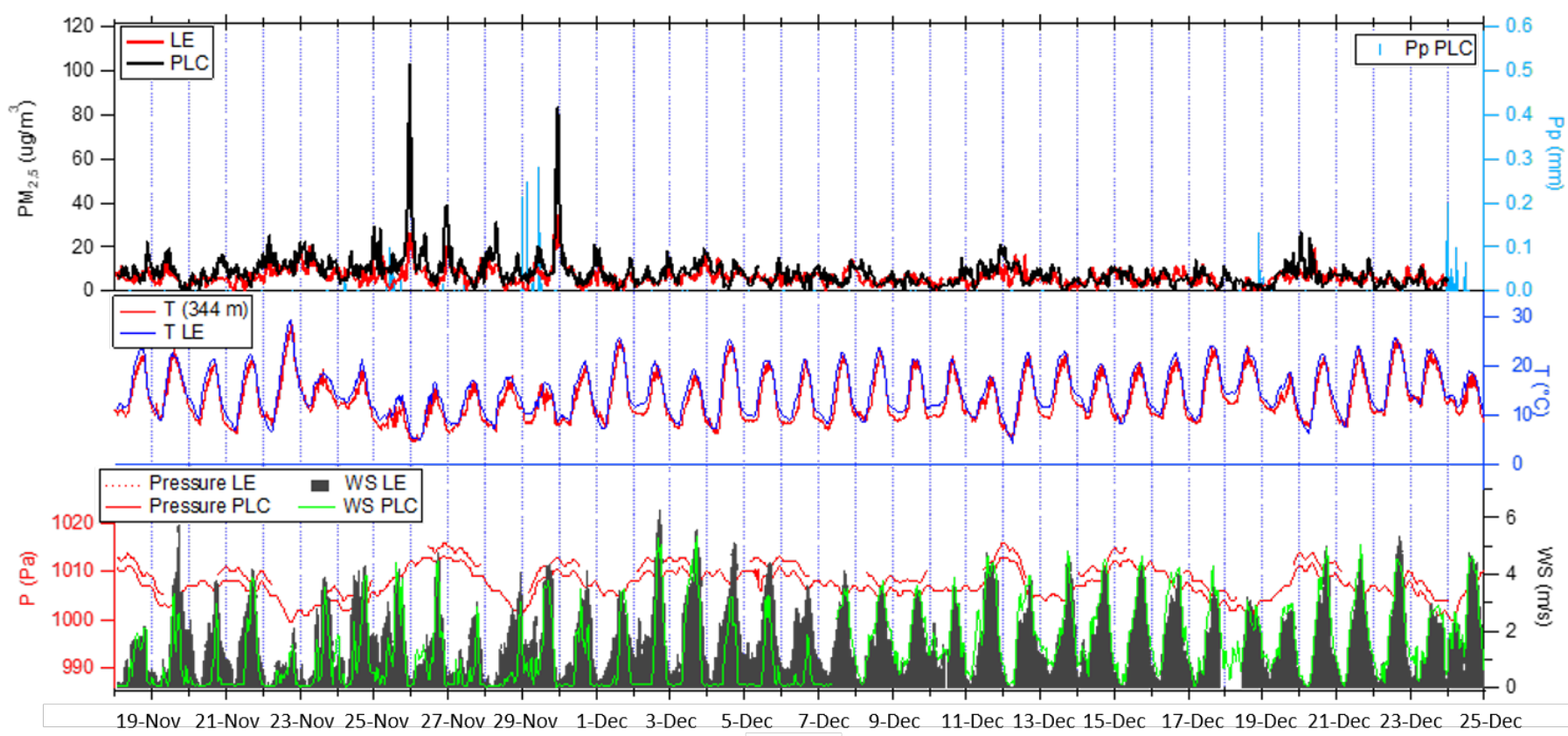

2019

Fig. 12. Time series of $P M_{2.5}$ concentration and meteorological parameters for the spring campaign in 2019. LE: Las Encinas station. PLC: Padre Las Casas station. P: Ambient pressure. WS: Wind direction. T: Temperature. Pp: Precipitation. 


\subsection{PM2.5 Elemental Composition and Monosaccharides}

In addition to real-time instruments that measured the main chemical species in $\mathrm{PM}_{1}$, the concentrations of several elements and MA's were analyzed from the $\mathrm{PM}_{2.5}$ filter samples. Significantly elevated MA concentrations were observed during wintertime (Table 3 ) at both PLC and LE. Elevated MA concentrations are typically observed in areas where biomass burning is a prevailing source (e.g., Wang et al., 2011, Saarnio et al., 2012). The largest elemental concentrations were measured for $\mathrm{P}, \mathrm{S}, \mathrm{Cl}, \mathrm{K}$ and $\mathrm{Ca}$ (Table 3). Note that elemental chlorine is marked differently (Cl) from ionic chloride measured by the ACSM (Chloride). Most of the elements had higher concentrations in winter than in spring, especially $\mathrm{K}, \mathrm{Cl}, \mathrm{Zn}$, and $\mathrm{Br}$ at both sites. Only $\mathrm{Al}$ had higher concentrations in spring than in winter at both measurement locations. When comparing the sites, the concentrations of the elements were mostly higher at Padre las Casas.

Several elements and monosaccharides determined in this study have been used as tracers of specific sources in other Chilean cities, such as biomass burning ( $\mathrm{K}, \mathrm{MA}$ 's, $\mathrm{Cl})$, vehicular emissions ( $\mathrm{Zn}$ and $\mathrm{Cr}$ ) and secondary components ( $\mathrm{S}$ in sulphate) (Barraza et al., 2017; Jhun et al., 2013; Kavouras et al., 2001; Villalobos et al., 2017). In this study, Cl and K correlated strongly with MA's $(R>0.8)$, indicating that they are related mostly to biomass burning emissions (Hedberg et al., 2002; McDonald et al., 2000). Zn showed a positive correlation with MA's ( $=0.75)$ and weak correlation with $\mathrm{Cr}(\mathrm{R}=0.22)$ indicating that the vehicular emissions, previously characterized by $\mathrm{Zn}$ and $\mathrm{Cr}$, were altered probably by a significant $\mathrm{Zn}$ contribution from wood burning emissions (Dilger et al., 2016; Molnár et al., 2005). At both sites, the $\mathrm{PM}_{2.5}$ concentration correlated strongly

Table 3. Seasonal average (average \pm standard deviation) of $\mathrm{PM}_{2.5}$ concentration and elements for the Padre Las Casas and Las Enchinas sites. Cells marked with "-" were not considered representative for the site/campaign as they had less than $75 \%$ of filter results available.

\begin{tabular}{|c|c|c|c|c|c|}
\hline \multirow{2}{*}{ Species } & & \multicolumn{2}{|c|}{ Padre Las Casas } & \multicolumn{2}{|c|}{ Las Encinas } \\
\hline & & Winter & Spring & Winter & Spring \\
\hline $\mathrm{PM}_{2.5}$ & $\left(\mu \mathrm{g} \mathrm{m}^{-3}\right)$ & $77.3 \pm 80.9$ & $8.6 \pm 3.8$ & $56.1 \pm 50.4$ & $6.7 \pm 2.4$ \\
\hline Levoglucosan & $\left(n g m^{-3}\right)$ & $8446 \pm 7406$ & $313.9 \pm 447.3$ & $8041.9 \pm 8118.1$ & $148.3 \pm 233.3$ \\
\hline Mannosan & $\left(n g m^{-3}\right)$ & $694.9 \pm 665$ & $29 \pm 42.7$ & $562.6 \pm 567$ & $11.9 \pm 18.9$ \\
\hline Galactosan & $\left(n g m^{-3}\right)$ & $596 \pm 529.2$ & $21.4 \pm 29$ & $641.6 \pm 698.1$ & $9.6 \pm 13.2$ \\
\hline $\mathrm{Na}$ & $\left(n g m^{-3}\right)$ & - & $68.3 \pm 27.8$ & $72.4 \pm 31.8$ & $66 \pm 29.1$ \\
\hline $\mathrm{Mg}$ & $\left(n g m^{-3}\right)$ & $86.7 \pm 34.9$ & - & $47.9 \pm 21.9$ & - \\
\hline $\mathrm{Al}$ & $\left(n g m^{-3}\right)$ & $86.2 \pm 30.4$ & $50.7 \pm 16.1$ & $46.6 \pm 21.7$ & $49.5 \pm 12.5$ \\
\hline $\mathrm{Si}$ & $\left(n g m^{-3}\right)$ & $26.5 \pm 24.4$ & $33.8 \pm 25.7$ & $19.8 \pm 16.6$ & $25.5 \pm 20$ \\
\hline$P$ & $\left(n g m^{-3}\right)$ & $170.9 \pm 17.2$ & $75 \pm 14.6$ & $77.3 \pm 13.7$ & $72.2 \pm 15.1$ \\
\hline S & $\left(n g m^{-3}\right)$ & $244.2 \pm 155$ & $110.4 \pm 40.3$ & $162.1 \pm 105.6$ & $100.6 \pm 38.8$ \\
\hline $\mathrm{Cl}$ & $\left(n g m^{-3}\right)$ & $833.3 \pm 708.4$ & $166.3 \pm 97.5$ & $540.1 \pm 487.2$ & $147.3 \pm 78.5$ \\
\hline K & $\left(n g m^{-3}\right)$ & $945 \pm 640.8$ & $106.5 \pm 44.9$ & $634.6 \pm 540.8$ & $73.8 \pm 31.9$ \\
\hline $\mathrm{Ca}$ & $\left(n g m^{-3}\right)$ & $180.5 \pm 69.4$ & $115.5 \pm 16.3$ & $102.7 \pm 23.7$ & $104.7 \pm 12.6$ \\
\hline Sc & $\left(n g m^{-3}\right)$ & $73.3 \pm 10.5$ & $20 \pm 3.8$ & $33.4 \pm 6.5$ & $19.3 \pm 4.2$ \\
\hline $\mathrm{Ti}$ & $\left(n g m^{-3}\right)$ & $23.2 \pm 6.3$ & $17.7 \pm 3.9$ & $13.4 \pm 3.5$ & $16.1 \pm 3$ \\
\hline $\mathrm{Cr}$ & $\left(n g m^{-3}\right)$ & $5.8 \pm 2.4$ & $2.8 \pm 0.9$ & $2.8 \pm 1.2$ & $2.8 \pm 1.1$ \\
\hline $\mathrm{Fe}$ & $\left(n g m^{-3}\right)$ & $76.2 \pm 47$ & $63.4 \pm 30.3$ & $57.1 \pm 46.3$ & $49 \pm 22.9$ \\
\hline $\mathrm{Cu}$ & $\left(n g m^{-3}\right)$ & $19.3 \pm 6.4$ & $6.5 \pm 2.1$ & $10.6 \pm 4.2$ & $5.9 \pm 1.7$ \\
\hline $\mathrm{Zn}$ & $\left(n g m^{-3}\right)$ & $51.1 \pm 18.4$ & $12.4 \pm 3.7$ & $30.6 \pm 19.7$ & $10 \pm 3.5$ \\
\hline $\mathrm{Br}$ & $\left(n g m^{-3}\right)$ & $13.5 \pm 9$ & $4.2 \pm 2.1$ & $7.1 \pm 4.7$ & $3.2 \pm 1.1$ \\
\hline Cs & $\left(n g m^{-3}\right)$ & - & - & $32.5 \pm 14.8$ & - \\
\hline La & $\left(n g m^{-3}\right)$ & $136.9 \pm 51.4$ & - & $63.9 \pm 30$ & - \\
\hline $\mathrm{Ce}$ & $\left(n g m^{-3}\right)$ & - & $43.3 \pm 22.2$ & $52 \pm 26.9$ & $40 \pm 25.8$ \\
\hline $\mathrm{Sm}$ & $\left(n g m^{-3}\right)$ & $235.5 \pm 90.1$ & - & $110.9 \pm 44.5$ & - \\
\hline $\mathrm{Eu}$ & $\left(n g m^{-3}\right)$ & $318.2 \pm 162.8$ & $171.5 \pm 65.7$ & $166.4 \pm 62.8$ & $157.2 \pm 73.7$ \\
\hline $\mathrm{Tb}$ & $\left(n g m^{-3}\right)$ & - & - & - & $116.6 \pm 45.9$ \\
\hline W & $\left(n g m^{-3}\right)$ & $27.4 \pm 13.7$ & $13.1 \pm 9.9$ & $12.7 \pm 8.1$ & $11.3 \pm 8.7$ \\
\hline $\mathrm{Pb}$ & $\left(n g m^{-3}\right)$ & $20.4 \pm 8.7$ & $5.3 \pm 1.7$ & $8.4 \pm 4.9$ & - \\
\hline
\end{tabular}


with $\mathrm{MA}^{\prime} \mathrm{s}, \mathrm{Cl}$ and $\mathrm{K}\left(\mathrm{R}^{2}>0.43\right)$ in the wintertime suggesting that biomass burning is the most important emission source in the zone. In spring, $\mathrm{MA}^{\prime}$ s showed lower $\mathrm{R}^{2}$ values with $\mathrm{PM}_{2.5}$ at both sites indicating a reduced impact of wood combustion sources. The role of biomass burning is comparable to the results from other places, e.g., China (Mehmood et al., 2018). In addition, elevated concentrations of several Lanthanide elements (i.e., La, Sm, Eu) were observed. The lanthanides are likely originating from the mining activities. Previous studies have observed elevated rare earth element concentrations in Chile in mine tailings as well as in atmospheric and environmental samples (Goecke et al., 2017, Mesías Monsalve et al., 2018, Rodriguez et al., 2021).

The levoglucosan/mannosan (L/M) ratio has been established as an indication of the type of wood used in the combustion (Gonçalves et al., 2010; Schmidl et al., 2011). In this study the ratio varied between 12 and 17 in winter without any clear difference between the sites. During the spring, the ratio was slightly smaller. The ratio obtained in this study has been typically observed for combustion of mostly Mediterranean species of hardwood (Schmidl et al., 2008). However, recent studies e.g., May et al. (2012) have reported levoglucosan volatilization at temperatures above $30^{\circ} \mathrm{C}$, limiting its tracer applicability in some field measurements. Considering that this study was conducted in the cold season with monthly average temperatures below $10^{\circ} \mathrm{C}$ (Fig. 2), the partitioning of levoglucosan into the gas phase can be considered negligible.

Previous studies have indicated that elements in atmospheric PM in Chile may originate e.g., from mining activities, traffic, industrial activities or resuspended dust (e.g., Sax et al., 2007, Mesías Monsalve et al., 2018, Saarikoski et al., 2019). The Cluster Heatmap analysis (Fig. S5 in the supplemental material) groups elements depending on their similarity during the campaign period. Attributable source(s) for these elements can be inferred and, generally some elements tend to cluster together depending on the method employed to group them. In our approach, we evaluated the daily behavior of the elemental contribution to $\mathrm{PM}_{2.5}$ as the number of standard deviations from the median for each element or compound. The patterns of the contribution of different elements and compounds to $\mathrm{PM}_{2.5}$ were clearly segregated by the season when they were collected (winter and spring represented by blue and yellow colours respectively in the y-axis). During winter, but not in spring, PLC and LE sites were mildly segregated, but generally a clear separation among the monitoring sites was not observed indicating a similar impact of common emissions sources at both sites. Elements and compounds (x-axis) were grouped in two clear clusters. Galactosan, levoglucosan and mannosan were grouped with $\mathrm{K}$, indicating a strong influence of biomass burning (Jorquera and Barraza, 2012) for that cluster. In contrast to all elements analysed, the contribution of the MA's to $\mathrm{PM}_{2.5}$ was higher during winter. The other distinctive cluster grouped all remaining elements. Although clear groups were not distinguished for this cluster, crustal elements such as (Ca, Al, Si, Fe) (Sax et al., 2007) were closely related but not forming a distinctive cluster. Similarly, $\mathrm{Pb}$ and $\mathrm{Br}$ (generally related to vehicular combustion, Gramsch et al., 2021) were close to each other but not in a distinctive cluster. In summary, the only sourceidentifiable cluster was biomass combustion, while additional sources were not cluster-defined and elements enriched in emissions from certain sources behaved similarly during the campaign period.

\section{SUMMARY AND CONCLUSIONS}

The results obtained from two measurement campaigns, carried out in winter and spring at the stations located at Temuco, Las Encinas and Padre las Casas, showed clearly that in winter the daily $\mathrm{PM}_{2.5}$ levels frequently exceeded the Chile's primary annual $\mathrm{PM}_{2.5}$ standard limit. To better understand the reasons for this non-compliance with the PM standard, advanced air quality measurement techniques and equipment, such as the ACSM, were implemented, which allows the real-time measurement of organics, sulphate, ammonium, nitrate and chloride together with the SIMCA monitor that measured black carbon. During the measurement campaigns, the samples of $\mathrm{PM}_{10}$ and $\mathrm{PM}_{2.5}$ were collected in Teflon filters with Harvard impactors, creating an important database of elements and monosaccharides, which together with the PM composition, concentration, and meteorological data, allowed the identification of the main sources of pollutants impacting the air quality in Las Encinas and Padre las Casas.

The main component in submicron particles was organic matter that contributed almost $90 \%$ of 
the analyzed $\mathrm{PM}_{1}$ components in winter with the mean winter concentrations of 30 and $62 \mu \mathrm{g} \mathrm{m}^{-3}$ at LE and PLC, respectively. In spring, the concentrations of organics were 10-20 times smaller. The average contribution of inorganic ions to the analyzed $\mathrm{PM}_{1}$ components varied from 9 to $30 \%$ being larger in spring than in winter. Similarly, the contribution of BC was smaller during winter $(\sim 3 \%)$ than during spring (11-13\%) at both sites.

Biomass combustion had high impact on $\mathrm{PM}_{2.5}$ in wintertime at both sites. The biomass burning tracers, monosaccharides, potassium and chloride, were elevated in the wintertime and their diurnal profiles showed an increase in concentrations in the evening. The contribution of MA's to $\mathrm{PM}_{2.5}$ was 11 and $20 \%$ at PLC and LE, respectively, in winter, while the contribution was $3-4 \%$ in the springtime pointing out a significant influence of biomass burning on $\mathrm{PM}_{2.5}$ in winter. Also, the contribution of biomass combustion to organic fraction and the aging of organic compounds was estimated based on the ACSM tracers' signals. The fraction of ion $\mathrm{m} / \mathrm{z} 60$, which is used as a tracer ion in biomass combustion, to organics in total organic mass spectra ( $f 60)$, showed higher values during winter and especially during colder temperatures. Diurnal profiles combined with the in-depth chemical analysis clearly showed that in the wintertime local biomass burning is the main source of air pollutants in the region. Furthermore, in winter, most of the high concentration events correlated with the periods with high surface pressure, low temperature, and low wind speed. These events matched with higher temperatures at high altitude than at the surface, characterizing the typical profile of a vertical inversion preventing the dilution of air pollutants.

In summary, the use of firewood as fuel in the studied area together with the unfavorable local meteorological parameters were observed to contribute to the development of poor air quality episodes in Temuco causing exceedances of the Chilean PM $_{2.5}$ standard. To achieve and comply with the $\mathrm{PM}_{10}$ and $\mathrm{PM}_{2.5}$ standard, the Chilean environmental authority must massively reduce the emissions from firewood combustion by prioritizing the use of non-polluting energy, control the quality of firewood, and inspect the correct use of the heaters together with educating the population in the efficient way to use wood as a fuel.

\section{ACKNOWLEDGEMENTS}

The authors are grateful for the participation and help of the staff of the Secretary of the Environment of the Araucanía region, led by Rocío Toro. This study was financed by the Ministry of the Environment, contract nr. 608897-27-LP19, Academy of Finland Flagship funding (grant no. 337552) and Business Finland via the BC Footprint Project (\# 528/31/2019).

\section{SUPPLEMENTARY MATERIAL}

Supplementary material for this article can be found in the online version at https://doi. org/10.4209/aaqr.210110

\section{REFERENCES}

Babicki, S., Arndt, D., Marcu, A., Liang, Y., Grant, J.R., Maciejewski, A., Wishart, D.S. (2016). Heatmapper: Web-enabled heat mapping for all. Nucleic Acids Res. 44, W147-W153. https://doi.org/10.1093/nar/gkw419

Barraza, F., Lambert, F., Jorquera, H., Villalobos, A.M., Gallardo, L. (2017). Temporal evolution of main ambient $\mathrm{PM}_{2.5}$ sources in Santiago, Chile, from 1998 to 2012. Atmos. Chem. Phys. 17, 10093-10107. https://doi.org/10.5194/acp-17-10093-2017

Burling, I.R., Yokelson, R.J., Griffith, D.W.T., Johnson, T.J., Veres, P., Roberts, J.M., Warneke, C., Urbanski, S.P., Reardon, J., Weise, D.R., Hao, W.M., de Gouw, J. (2010). Laboratory measurements of trace gas emissions from biomass burning of fuel types from the southeastern and southwestern United States. Atmos. Chem. Phys. 10, 11115-11130. https://doi.org/10.5194/acp-10-11115-2010

Burling, I.R., Yokelson, R.J., Akagi, S.K., Urbanski, S.P., Wold, C.E., Griffith, D.W.T., Johnson, T.J., Reardon, J., Weise, D.R. (2011). Airborne and ground-based measurements of the trace gases 
and particles emitted by prescribed fires in the United States. Atmos. Chem. Phys. 11, 1219712216. https://doi.org/10.5194/acp-11-12197-2011

Carbone, S., Saarikoski, S., Frey, A., Reyes, F., Reyes, P., Castillo, M., Gramsch, E., Oyola, P., Jayne, J., Worsnop, D.R., Hillamo, R. (2013). Chemical characterization of submicron aerosol particles in Santiago de Chile. Aerosol Air Qual. Res. 13, 462-473. https://doi.org/10.4209/aaqr.2012.1 0.0261

Cereceda-Balic, F., Fadic, X., Llanos, A.L., Dominguez, A.M., Guevara, J.L., Vidal, V., Díaz-Robles, L.A., Schiappacasse, L.N., Etcharren, P. (2012). Obtaining polycyclic aromatic hydrocarbon concentration ratios and molecular markers for residential wood combustion: Temuco, a case study. J. Air Waste Manage. Assoc. 62, 44-51. https://doi.org/10.1080/10473289.2011.617599

Cereceda-Balic, F., Toledo, M., Vidal, V., Guerrero, F., Diaz-Robles, L.A., Petit-Breuilh, X., Lapuerta, M. (2017). Emission factors for $\mathrm{PM}_{2.5}, \mathrm{CO}, \mathrm{CO}_{2}, \mathrm{NO}_{x}, \mathrm{SO}_{2}$ and particle size distributions from the combustion of wood species using a new controlled combustion chamber 3CE. Sci. Total Environ. 584-585, 901-910. https://doi.org/10.1016/j.scitotenv.2017.01.136

Chen, J., Li, C., Ristovski, Z., Milic, A., Gu, Y., Islam, M.S., Wang, S., Hao, J., Zhang, H., He, C., Guo, H., Fu, H., Miljevic, B., Morawska, L., Thai, P., Lam, Y.F., Pereira, G., Ding, A., Huang, X., Dumka, U.C. (2017). A review of biomass burning: Emissions and impacts on air quality, health and climate in China. Sci. Total Environ. 579, 1000-1034. https://doi.org/10.1016/j.scitotenv.2016. 11.025

Cubison, M.J., Ortega, A.M., Hayes, P.L., Farmer, D.K., Day, D., Lechner, M.J., Brune, W.H., Apel, E., Diskin, G.S., Fisher, J.A., Fuelberg, H.E., Hecobian, A., Knapp, D.J., Mikoviny, T., Riemer, D., Sachse, G.W., Sessions, W., Weber, R.J., Weinheimer, A.J., Wisthaler, A., Jimenez, J.L. (2011). Effects of aging on organic aerosol from open biomass burning smoke in aircraft and laboratory studies. Atmos. Chem. Phys. 11, 12049-12064. https://doi.org/10.5194/acp-11-12049-2011

Díaz-Robles, L., Cortés, S., Vergara-Fernández, A., Ortega, J.C. (2015). Short term health effects of particulate matter: A comparison between wood smoke and multi-source polluted urban areas in Chile. Aerosol Air Qual. Res. 15, 306-318. https://doi.org/10.4209/aaqr.2013.10.0316

Díaz-Robles, L.A., Fu, J.S., Vergara-Fernández, A., Etcharren, P., Schiappacasse, L.N., Reed, G.D., Silva, M.P. (2014). Health risks caused by short term exposure to ultrafine particles generated by residential wood combustion: A case study of Temuco, Chile. Environ Int. 66, 174-181. https://doi.org/10.1016/j.envint.2014.01.017

Dilger, M., Orasche, J., Zimmermann, R., Paur, H.R., Diabaté, S., Weiss, C. (2016). Toxicity of wood smoke particles in human A549 lung epithelial cells: The role of PAHs, soot and zinc. Arch. Toxicol. 90, 3029-3044. https://doi.org/10.1007/s00204-016-1659-1

Fang, Z., Li, C., He, Q., Czech, H., Gröger, T., Zeng, J., Fang, H., Xiao, S., Pardo, M., Hartner, E., Meidan, D., Wang, X., Zimmermann, R., Laskin, A., Rudich, Y. (2021). Secondary organic aerosols produced from photochemical oxidation of secondarily evaporated biomass burning organic gases: Chemical composition, toxicity, optical properties, and climate effect. Environ. Int. 157, 106801, https://doi.org/10.1016/j.envint.2021.106801

Gani, S., Bhandari, S., Seraj, S., Wang, D.S., Patel, K., Soni, P., Arub, Z., Habib, G., Hildebrandt Ruiz, L., Apte, J.S. (2019). Submicron aerosol composition in the world's most polluted megacity: The Delhi Aerosol Supersite study. Atmos. Chem. Phys. 19, 6843-6859. https://doi.org/10.519 4/acp-19-6843-2019

Goecke, F., Aránguiz-Acuña, A., Palacios, M., Muñoz-Muga, P., Rucki, M., Vítová, M. (2017). Latitudinal distribution of lanthanides contained in macroalgae in Chile: An inductively coupled plasma-mass spectrometric (ICP-MS) determination. J. Appl. Phycol. 29, 2117-2128, https://doi.org/10.1007/s10811-017-1106-6

Gonçalves, C., Alves, C., Evtyugina, M., Mirante, F., Pio, C., Caseiro, A., Schmidl, C., Bauer, H., Carvalho, F. (2010). Characterisation of $\mathrm{PM}_{10}$ emissions from woodstove combustion of common woods grown in Portugal. Atmos. Environ. 44, 4474-4480. https://doi.org/10.1016/j. atmosenv.2010.07.026

Gramsch, E., Catalán, L., Ormeño, I., Palma, G. (2000). Traffic and seasonal dependence of the light absorption coefficient in Santiago de Chile. Appl. Opt. 39, 4895-4901.

Gramsch, E., Ormeño, I., Palma, G., Cereceda-Balic, F., Oyola, P. (2004). Use of the light absorption coefficient to monitor elemental carbon and $\mathrm{PM}_{2.5}$-Example of Santiago de Chile. J. Air Waste Manage. Assoc. 54, 799-808. https://doi.org/10.1080/10473289.2004.10470956 
Gramsch, E., Cereceda-Balic, F., Oyola, P., von Baer, D. (2006). Examination of pollution trends in Santiago de Chile with cluster analysis of $\mathrm{PM}_{10}$ and Ozone data. Atmos. Environ. 40, 54645475. https://doi.org/10.1016/j.atmosenv.2006.03.062

Gramsch, E., Le Nir, G., Araya, M., Rubio, M.A., Moreno, F., Oyola, P. (2013). Influence of large changes in public transportation (Transantiago) on the black carbon pollution near streets. Atmos. Environ. 65, 153-163. https://doi.org/10.1016/j.atmosenv.2012.10.006

Gramsch, E., Cáceres, D., Oyola, P., Reyes, F., Vásquez, Y., Rubio, M.A., Sánchez, G. (2014a). Influence of surface and subsidence thermal inversion on $\mathrm{PM}_{2.5}$ and black carbon concentration. Atmos. Environ. 98, 290-298. https://doi.org/10.1016/j.atmosenv.2014.08.066

Gramsch, E., Reyes, F., Oyola, P., Rubio, M.A., López, G., Pérez, P., Martínez, R. (2014b). Particle size distribution and its relationship to black carbon in two urban and one rural site in Santiago de Chile. J. Air Waste Manage. Assoc. 64, 785-796. https://doi.org/10.1080/10962247.2014.8 90141

Gramsch, E., Reyes, F., Vásquez, Y., Oyola, P., Rubio, M.A. (2016). Prevalence of freshly generated particles during pollution episodes in Santiago de Chile. Aerosol Air Qual. Res. 16, 2172-2185. https://doi.org/10.4209/aaqr.2015.12.0691

Gramsch, E., Oyola, P., Reyes, F., Rojas, F., Henriquez, A., Kang, C. (2021). Trends in particle matter and its elemental composition in Santiago de Chile, 2011-2018. J. Air Waste Manage. Assoc. 71, 721-736. https://doi.org/10.1080/10962247.2021.1877211

Hedberg, E., Kristensson, A., Ohlsson, M., Johansson, C., Johansson, P.Å., Swietlicki, E., Vesely, V., Wideqvist, U., Westerholm, R. (2002). Chemical and physical characterization of emissions from birch wood combustion in a wood stove. Atmos. Environ. 36, 4823-4837. https://doi.org/ 10.1016/S1352-2310(02)00417-X

Helin, A., Niemi, J.V., Virkkula, A., Pirjola, L., Teinilä, K., Backman, J., Aurela, M., Saarikoski, S., Rönkkö, T., Asmi, E., Timonen, H. (2018). Characteristics and source apportionment of black carbon in the Helsinki metropolitan area, Finland. Atmos. Environ. 190, 87-98. https://doi.org/ 10.1016/j.atmosenv.2018.07.022

Holder, A.L., Gullett, B.K., Urbanski, S.P., Elleman, R., O’Neill, S., Tabor, D., Mitchell, W., Baker, K.R. (2017). Emissions from prescribed burning of agricultural fields in the Pacific Northwest. Atmos. Environ. 166, 22-33. https://doi.org/10.1016/j.atmosenv.2017.06.043

Horvath, H. (1997). Experimental calibration for aerosol light absorption measurements using the integrating plate method-Summary of the data. J. Aerosol Sci. 28, 1149-1161. https://doi.org/10.1016/S0021-8502(97)00007-4

Huang, K., Liang, F., Yang, X., Liu, F., Li, J., Xiao, Q., Chen, J., Liu, X., Cao, J., Shen, C., Yu, L., Lu, F., Wu, Xianping, Zhao, L., Wu, Xigui, Li, Y., Hu, D., Huang, J., Liu, Y., Lu, X., Gu, D. (2019). Long term exposure to ambient fine particulate matter and incidence of stroke: Prospective cohort study from the China-PAR project. BMJ. 367, 16720. https://doi.org/10.1136/bmj.16720

Huang, X.F., He, L.Y., Hu, M., Canagaratna, M.R., Sun, Y., Zhang, Q., Zhu, T., Xue, L., Zeng, L.W., Liu, X.G., Zhang, Y.H., Jayne, J.T., Ng, N.L., Worsnop, D.R. (2010). Highly time-resolved chemical characterization of atmospheric submicron particles during 2008 Beijing Olympic Games using an Aerodyne High-Resolution Aerosol Mass Spectrometer. Atmos. Chem. Phys. 10, 8933-8945. https://doi.org/10.5194/acp-10-8933-2010

IPCC (2014). Climate Change 2014: Synthesis Report. Contribution of Working Groups I, II and III to the Fifth Assessment Report of the Intergovernmental Panel on Climate Change. Core Writing Team, Pachauri, R.K., Meyer, L.A. (Eds.), IPCC, Geneva, Switzerland, 151 pp.

Jhun, I., Oyola, P., Moreno, F., Castillo, M.A., Koutrakis, P. (2013). PM2.5 mass and species trends in Santiago, Chile, 1998 to 2010: The impact of fuel-related interventions and fuel sales. J. Air Waste Manage. Assoc. 63, 161-169. https://doi.org/10.1080/10962247.2012.742027

Jimenez, J.L., Canagaratna, M.R., Donahue, N.M., Prevot, A.S.H., Zhang, Q., Kroll, J.H., DeCarlo, P.F., Allan, J.D., Coe, H., Ng, N.L., Aiken, A.C., Docherty, K.S., Ulbrich, I.M., Grieshop, A.P., Robinson, A.L., Duplissy, J., Smith, J.D., Wilson, K.R., Lanz, V.A., Hueglin, C., et al. (2009). Evolution of organic aerosols in the atmosphere. Science 326, 1525-1529. https://doi.org/10. 1126/science.1180353

Jorquera, H., Barraza, F. (2012). Source apportionment of ambient PM2.5 in Santiago, Chile: 1999 and 2004 results. Sci. Total Environ. 435-416, 418-29. https://doi.org/10.1016/j.scitotenv.201 2.07.049 
Jorquera, H., Barraza, F., Heyer, J., Valdivia, G., Schiappacasse, L.N., Montoya, L.D. (2018). Indoor $\mathrm{PM}_{2.5}$ in an urban zone with heavy wood smoke pollution: The case of Temuco, Chile. Environ. Pollut. 236, 477-487. https://doi.org/10.1016/j.envpol.2018.01.085

Kavouras, I.G., Koutrakis, P., Cereceda-Balic, F., Oyola, P. (2001). Source apportionment of PM10 and $\mathrm{PM}_{2.5}$ in five Chilean cities using factor analysis. J. Air Waste Manage. Assoc. 51, 451-464. https://doi.org/10.1080/10473289.2001.10464273

Kortelainen, M., Jokiniemi, J., Tiitta, P., Tissari, J., Lamberg, H., Leskinen, J., Grigonyte-Lopez Rodriguez, J., Koponen, H., Antikainen, S., Nuutinen, I., Zimmermann, R., Sippula, O. (2018). Time-resolved chemical composition of small-scale batch combustion emissions from various wood species. Fuel 233, 224-236, https://doi.org/10.1016/j.fuel.2018.06.056

Langner, J., Gidhagen, L., Bergström, R., Gramsch, E., Oyola, P., Reyes, F., Segersson, D., Aguilera, C. (2020). Model simulated source contributions to $\mathrm{PM}_{2.5}$ in Santiago and in the central region of Chile. Aerosol Air Qual. Res. 20, 1111-1126. https://doi.org/10.4209/aaqr.2019.08.0374

Lelieveld, J., Evans, J.S., Fnais, M., Giannadaki, D., Pozzer, A. (2015). The contribution of outdoor air pollution sources to premature mortality on a global scale. Nature 525, 367-371. https://doi.org/10.1038/nature15371

Lindenmayer, D.B., Taylor, C. (2020). New spatial analyses of Australian wildfires highlight the need for new fire, resource, and conservation policies. PNAS 117, 12481-12485. https://doi.org/10.1073/pnas.2002269117

Lorelei de Jesus, A., Thompson, H., Knibbs, L.D., Kowalski, M., Cyrys, J., Niemi, J.V., Kousa, A., Timonen, H., Luoma, K., Petäjä, T., Beddows, D., Harrison, R.M., Hopke, P., Morawska, L. (2020). Long-term trends in $\mathrm{PM}_{2.5}$ mass and particle number concentrations in urban air: The impacts of mitigation measures and extreme events due to changing climates. Environ. Pollut. 263, 114500. https://doi.org/10.1016/j.envpol.2020.114500

Marple, V.A., Willeke, K. (1976). Impactor design. Atmos. Environ. 10, 891-896. https://doi.org/ 10.1016/0004-6981(76)90144-X

May, A.A., Saleh, R., Hennigan, C.J., Donahue, N.M., Robinson, A.L. (2012). Volatility of organic molecular markers used for source apportionment analysis: Measurements and implications for atmospheric lifetime. Environ. Sci. Technol. 46, 12435-12444. https://doi.org/10.1021/es3 $02276 \mathrm{t}$

McDonald, J.D., Zielinska, B., Fujita, E.M., Sagebiel, J.C., Chow, J.C., Watson, J.G. (2000). Fine particle and gaseous emission rates from residential wood combustion. Environ. Sci. Technol. 34, 2080-2091. https://doi.org/10.1021/es9909632

Mehmood, K., Chang, S., Yu, S., Wang, L., Li, P., Li, Z., Liu, W., Rosenfeld, D., Seinfeld, J. H. (2018). Spatial and temporal distributions of air pollutant emissions from open crop straw and biomass burnings in China from 2002 to 2016. Environ. Chem. Lett. 16, 301-309. https://doi.org/10.10 07/s10311-017-0675-6

Mehmood, K., Wu, Y., Wang, L., Yu, S., Li, P., Chen, X., Li, Z., Zhang, Y., Li, M., Liu, W., Wang, Y., Liu, Z., Zhu, Y., Rosenfeld, D., Seinfeld, J.H. (2020). Relative effects of open biomass burning and open crop straw burning on haze formation over central and eastern China: Modeling study driven by constrained emissions. Atmos. Chem. Phys. 20, 2419-2443. https://doi.org/10. 5194/acp-20-2419-2020

Mesías Monsalve, S., Martínez, L., Yohannessen Vásquez, K., Alvarado Orellana, S., Klarián Vergara, J., Martín Mateo, M., Costilla Salazar, R., Fuentes Alburquenque, M., Cáceres Lillo, D.D. (2018). Trace element contents in fine particulate matter $\left(\mathrm{PM}_{2.5}\right)$ in urban school microenvironments near a contaminated beach with mine tailings, Chañaral, Chile. Environ. Geochem. Health 40, 1077-1091. https://doi.org/10.1007/s10653-017-9980-z

Ministerio del Medio Ambiente (MMA) (2015). Decreto N8/2015 Plan de descontaminación atmosférica por MP 2,5, para las comunas de Temuco y Padre Las Casas y de actualización del plan de descontaminación por MP 10, para las mismas comunas. Decreto-8 17-NOV-2015 Ministerio del Medio Ambiente - Ley Chile - Biblioteca del Congreso Nacional (bcn.cl).

Molnár, P., Gustafson, P., Johannesson, S., Boman, J., Barregård, L., Sällsten, G. (2005). Domestic wood burning and $\mathrm{PM}_{2.5}$ trace elements: Personal exposures, indoor and outdoor levels. Atmos. Environ. 39, 2643-2653. https://doi.org/10.1016/j.atmosenv.2005.01.016

Ng, N.L., Canagaratna, M.R., Jimenez, J.L., Chhabra, P.S., Seinfeld, J.H., Worsnop, D.R. (2011a). Changes in organic aerosol composition with aging inferred from aerosol mass spectra. Atmos. 
Chem. Phys. 11, 6465-6474. https://doi.org/10.5194/acp-11-6465-2011

Ng, N.L., Herndon, S.C., Trimborn, A., Canagaratna, M.R., Croteau, P.L., Onasch, T.B., Sueper, D., Worsnop, D.R., Zhang, Q., Sun, Y.L., Jayne, J.T. (2011b). An aerosol chemical speciation monitor (ACSM) for routine monitoring of the composition and mass concentrations of ambient aerosol. Aerosol Sci. Technol. 45, 780-794. https://doi.org/10.1080/02786826.2011.560211

Ortega, A.M., Day, D.A., Cubison, M.J., Brune, W.H., Bon, D., de Gouw, J.A., Jimenez, J.L. (2013). Secondary organic aerosol formation and primary organic aerosol oxidation from biomassburning smoke in a flow reactor during FLAME-3. Atmos. Chem. Phys. 13, 11551-11571. https://doi.org/10.5194/acp-13-11551-2013

Saarikoski, S., Reyes, F., Vázquez, Y., Tagle, M., Timonen, H., Aurela, M., Carbone, S., Worsnop, D.R., Hillamo, R., Oyola, P. (2019). Characterization of submicron aerosol chemical composition and sources in the coastal area of Central Chile. Atmos. Environ. 199, 391-401. https://doi.org/ 10.1016/j.atmosenv.2018.11.040

Saarnio, K., Niemi, J. V., Saarikoski, S., Aurela, M., Timonen, H., Teinilä, K., Myllynen, M., Frey, A., Lamberg, H., Jokiniemi, J., Hillamo, R. (2012). Using monosaccharide anhydrides to estimate the impact of wood combustion on fine particles in the Helsinki Metropolitan Area. Boreal Environ. Res. 17, 164-183.

Sanhueza, P.A., Torreblanca, M.A., Diaz-Robles, L.A., Schiappacasse, L.N., Silva, M.P., Astete, T.D. (2009). Particulate air pollution and health effects for cardiovascular and respiratory causes in Temuco, Chile: A wood-smoke-polluted urban area. J. Air Waste Manage. Assoc. 59, 14811488. https://doi.org/10.3155/1047-3289.59.12.1481

Sax, S.N., Koutrakis, P., Rudolph, P.A.R., Cereceda-Balic, F., Gramsch, E., Oyola, P. (2007). Trends in the elemental composition of fine particulate matter in Santiago, Chile, from 1998 to 2003. J. Air Waste Manage. Assoc. 57, 845-855. https://doi.org/10.3155/1047-3289.57.7.845

Schmidl, C., Luisser, M., Padouvas, E., Lasselsberger, L., Rzaca, M., Ramirez-Santa Cruz, C., Handler, M., Peng, G., Bauer, H., Puxbaum, H. (2011). Particulate and gaseous emissions from manually and automatically fired small scale combustion systems. Atmos. Environ. 45, 74437454. https://doi.org/10.1016/j.atmosenv.2011.05.006

Schueftan, A., González, A.D. (2015). Proposals to enhance thermal efficiency programs and air pollution control in south-central Chile. Energy Policy 79, 48-57. https://doi.org/10.1016/j.en pol.2015.01.008

Sumlin, B.J., Pandey, A., Walker, M.J., Pattison, R.S., Williams, B.J., Chakrabarty, R.K. (2017). Atmospheric photooxidation diminishes light absorption by primary brown carbon aerosol from biomass burning. Environ. Sci. Technol. Lett. 4, 540-545. https://doi.org/10.1021/acs.estl ett.7b00393

Tagle, M., Reyes, F., Vásquez, Y., Carbone, S., Saarikoski, S., Timonen, H., Gramsch, E., Oyola, P. (2018). Spatiotemporal variation in composition of submicron particles in Santiago Metropolitan Region, Chile. Front. Environ. Sci. 6, 27. https://doi.org/10.3389/fenvs.2018.00027

Villalobos, A.M., Barraza, F., Jorquera, H., Schauer, J.J. (2017). Wood burning pollution in southern Chile: $\mathrm{PM}_{2.5}$ source apportionment using $\mathrm{CMB}$ and molecular markers. Environ. Pollut. 225, 514-523. https://doi.org/10.1016/j.envpol.2017.02.069

Wang, G., Chen, C., Li, J., Zhou, B., Xie, M., Hu, S., Kawamura, K., Chen, Y. (2011). Molecular composition and size distribution of sugars, sugar-alcohols and carboxylic acids in airborne particles during a severe urban haze event caused by wheat straw burning. Atmos. Environ. 45, 2473-2479, https://doi.org/10.1016/j.atmosenv.2011.02.045

Wang, S., Nan, J., Shi, C., Fu, Q., Gao, S., Wang, D., Cui, H., Saiz-Lopez, A., Zhou, B. (2015). Atmospheric ammonia and its impacts on regional air quality over the megacity of Shanghai, China. Sci. Rep. 5, 15842. https://doi.org/10.1038/srep15842

Wild, R.J., Dubé, W.P., Aikin, K.C., Eilerman, S.J., Neuman, J.A., Peischl, J., Ryerson, T.B., Brown, S.S. (2017). On-road measurements of vehicle $\mathrm{NO}_{2} / \mathrm{NO}_{x}$ emission ratios in Denver, Colorado, USA. Atmos. Environ. 148, 182-189. https://doi.org/10.1016/j.atmosenv.2016.10.039

Yokelson, R.J., Griffith, D.W.T., Ward, D.E. (1996). Open-path Fourier transform infrared studies of large-scale laboratory biomass fires. J. Geophys. Res. 101, 21067-21080. https://doi.org/10. 1029/96JD01800 